\title{
Analysis of ozone and nitric acid in spring and summer Arctic pollution using aircraft, ground-based, satellite observations and MOZART-4 model: source attribution and partitioning
}

\author{
C. Wespes ${ }^{1}$, L. Emmons ${ }^{1}$, D. P. Edwards ${ }^{1}$, J. Hannigan ${ }^{1}$, D. Hurtmans ${ }^{2}$, M. Saunois ${ }^{1}$, P.-F. Coheur ${ }^{2}$, C. Clerbaux ${ }^{2,3}$, \\ M. T. Coffey ${ }^{1}$, R. L. Batchelor ${ }^{1}$, R. Lindenmaier ${ }^{4}$, K. Strong ${ }^{4}$, A. J. Weinheimer ${ }^{1}$, J. B. Nowak ${ }^{5,6}$, T. B. Ryerson $^{5}$, \\ J. D. Crounse ${ }^{7}$, and P. O. Wennberg ${ }^{7}$ \\ ${ }^{1}$ National Center for Atmospheric Research, Boulder, CO, USA \\ ${ }^{2}$ Chimie Quantique et Photophysique, Université Libre de Bruxelles, Brussels, Belgium \\ ${ }^{3}$ UPMC Univ. Paris 6; Université Versailles St.-Quentin, CNRS/INSU, LATMOS-IPSL, Paris, France \\ ${ }^{4}$ Department of Physics, University of Toronto, Toronto, ON, Canada \\ ${ }^{5}$ NOAA, Earth System Research Laboratory, Boulder, CO, USA \\ ${ }^{6}$ Cooperative Institute for Research in Environmental Sciences (CIRES), University of Colorado, Boulder, CO, USA \\ ${ }^{7}$ California Institute of Technology, Pasadena, CA, USA
}

Correspondence to: C. Wespes (wespes@ucar.edu)

Received: 13 July 2011 - Published in Atmos. Chem. Phys. Discuss.: 22 August 2011

Revised: 12 December 2011 - Accepted: 14 December 2011 - Published: 4 January 2012

\begin{abstract}
In this paper, we analyze tropospheric $\mathrm{O}_{3}$ together with $\mathrm{HNO}_{3}$ during the POLARCAT (Polar Study using Aircraft, Remote Sensing, Surface Measurements and Models, of Climate, Chemistry, Aerosols, and Transport) program, combining observations and model results. Aircraft observations from the NASA ARCTAS (Arctic Research of the Composition of the Troposphere from Aircraft and Satellites) and NOAA ARCPAC (Aerosol, Radiation and Cloud Processes affecting Arctic Climate) campaigns during spring and summer of 2008 are used together with the Model for Ozone and Related Chemical Tracers, version 4 (MOZART4) to assist in the interpretation of the observations in terms of the source attribution and transport of $\mathrm{O}_{3}$ and $\mathrm{HNO}_{3}$ into the Arctic (north of $60^{\circ} \mathrm{N}$ ). The MOZART-4 simulations reproduce the aircraft observations generally well (within $15 \%$ ), but some discrepancies in the model are identified and discussed. The observed correlation of $\mathrm{O}_{3}$ with $\mathrm{HNO}_{3}$ is exploited to evaluate the MOZART-4 model performance for different air mass types (fresh plumes, free troposphere and stratospheric-contaminated air masses).

Based on model simulations of $\mathrm{O}_{3}$ and $\mathrm{HNO}_{3}$ tagged by source type and region, we find that the anthropogenic pollution from the Northern Hemisphere is the dominant source of $\mathrm{O}_{3}$ and $\mathrm{HNO}_{3}$ in the Arctic at pressures greater than $400 \mathrm{hPa}$, and that the stratospheric influence is the principal contribu-
\end{abstract}

tion at pressures less $400 \mathrm{hPa}$. During the summer, intense Russian fire emissions contribute some amount to the tropospheric columns of both gases over the American sector of the Arctic. North American fire emissions (California and Canada) also show an important impact on tropospheric ozone in the Arctic boundary layer.

Additional analysis of tropospheric $\mathrm{O}_{3}$ measurements from ground-based FTIR and from the IASI satellite sounder made at the Eureka (Canada) and Thule (Greenland) polar sites during POLARCAT has been performed using the tagged contributions. It demonstrates the capability of these instruments for observing pollution at northern high latitudes. Differences between contributions from the sources to the tropospheric columns as measured by FTIR and IASI are discussed in terms of vertical sensitivity associated with these instruments. The first analysis of $\mathrm{O}_{3}$ tropospheric columns observed by the IASI satellite instrument over the Arctic is also provided. Despite its limited vertical sensitivity in the lowermost atmospheric layers, we demonstrate that IASI is capable of detecting low-altitude pollution transported into the Arctic with some limitations. 


\section{Introduction}

As a part of the international POLARCAT (Polar Study using Aircraft, Remote Sensing, Surface Measurements and Models, of Climate, Chemistry, Aerosols, and Transport) program of field observations of Arctic atmospheric composition during the 2007-2008 International Polar Year, the Arctic Research of the Composition of the Troposphere from Aircraft and Satellites (ARCTAS) and Aerosol, Radiation, and Cloud Processes affecting Arctic Climate (ARCPAC) missions were conducted during spring and summer 2008 to better understand factors driving change in the atmospheric composition and climate of the Arctic (Jacob et al., 2010; Brock et al., 2011). Cool surface temperature and stable conditions characteristic of the Arctic atmosphere facilitate lowaltitude isentropic transport into this region, making it a major receptor for mid-latitude pollution (Klonecki et al., 2003; Stohl, 2006). This process produces the so-called "Arctic Haze", a recurring phenomenon observed every winter and spring, that results from long-range transport of aerosols and persistent pollutants such as mercury and ozone $\left(\mathrm{O}_{3}\right)$. Previous studies based on Arctic measurements from ground stations, aircraft, sondes and satellites, which provide observations of several trace species, show that the Arctic troposphere is strongly influenced by emissions from Europe, North America and Asia. They particularly showed that transport from anthropogenic source regions occurs through different processes at different altitudes: near-surface pollution is dominated by Northern European and North American sources, while Asian sources are the dominant contributors at higher altitudes (e.g., Stohl, 2006; Shindell et al., 2008; Fisher et al., 2010; Tilmes et al., 2011). They also highlight the strong impact of boreal forest fires in North America, Asia and Eastern Europe on the Arctic atmospheric pollution (e.g., Generoso et al., 2007; Leung et al., 2007; Turquety et al., 2007; Stohl et al., 2007; Fisher et al., 2010; Tilmes et al., 2011). However, despite the major interest in Arctic pollution for air quality and climate concerns, there remains considerable uncertainty concerning the source-receptor relationships between mid-latitude and Arctic atmospheric pollution throughout the troposphere (Shindell et al., 2008).

The ARCTAS and ARCPAC aircraft campaigns, which cover periods of several weeks in spring and summer, provide a large and suitable observational dataset for studying the long-range transport of pollution into the Arctic. The spring period offers a good opportunity to observe Asian influence, which is less understood than transport from Europe. This period is also favorable in terms of photochemistry controlling ozone production (Jacob et al., 2010) and of stratosphere-troposphere exchange affecting tropospheric ozone and nitric acid $\left(\mathrm{HNO}_{3}\right)$ in the Arctic. A primary goal of the summer deployment of ARCTAS was to better characterize boreal fire emissions, the chemical evolution within the fire plumes, and the regional scale impact of these forest fires. Another research theme of ARCTAS was to better un- derstand the chemical processes controlling nitrogen oxides $\left(\mathrm{NO}_{\mathrm{x}}\right)$ in the Arctic (Jacob et al., 2010). $\mathrm{NO}_{\mathrm{x}}$ plays an essential role in the processes that control the ozone abundance in the lower atmosphere. $\mathrm{HNO}_{3}$ is one of the principal reservoir species for the nitrogen oxides. Ozone and nitric acid can either be produced in mid-latitude source regions or during transport into the Arctic from the $\mathrm{NO}_{\mathrm{x}}$ precursors. Ozone production is limited by oxidation of $\mathrm{NO}_{\mathrm{x}}$ to reservoirs, such as PAN (peroxyacetlynitrate) and $\mathrm{HNO}_{3}$. Correlations between $\mathrm{NO}_{\mathrm{x}}, \mathrm{NO}_{\mathrm{y}}$ (the sum of all reactive nitrogen species) and $\mathrm{O}_{3}$ have frequently been used as a probe of chemistry and transport in the lower atmosphere (Murphy et al., 1993; Trainer et al., 1993; Ridley, et al., 1994; Singh et al., 1996; Fischer et al., 2000, Zellweger et al., 2003). Strong correlations between $\mathrm{HNO}_{3}$ and $\mathrm{O}_{3}$ were established in the lower stratosphere/upper troposphere and have been used previously to characterize air masses in the Arctic and midlatitude regions (Bregman et al., 1995; Talbot et al., 1997; Schneider et al., 1999; Neuman et al., 2001; Popp et al., 2009), to validate satellite $\mathrm{HNO}_{3}$ profiles (Irie et al., 2006; Popp et al., 2009), or to infer the efficiency of ozone production (Cooper et al., 2011). Study of the correlation of $\mathrm{HNO}_{3}$ and $\mathrm{O}_{3}$ in the lower/middle troposphere is less common, despite its importance in quantifying the dependence of ozone on nitrogen compounds. The DC- 8 aircraft from the spring and summer ARCTAS mission, as well as the concurrent NOAA WP-3D aircraft for the ARCPAC campaign (Brock et al., 2011), provide relevant information for this purpose.

Another central motivation for the ARCTAS campaign was to augment and interpret satellite observations of atmospheric composition (Jacob et al., 2010). Here, we show that the high spatiotemporal coverage of the Infrared Atmospheric Sounding Interferometer (IASI) instrument, launched onboard the polar orbiting MetOp satellite in October 2006, provides an excellent platform for observing the long-range transport of mid-latitude pollution into the Arctic. The comparison of satellite retrievals with aircraft data and chemistry transport model simulations provides a useful evaluation of the capability of satellites to measure Arctic atmospheric composition.

We present in this paper an analysis of the sources and the transport of Arctic pollution of $\mathrm{O}_{3}$ and $\mathrm{HNO}_{3}$ during spring and summer 2008 using a combination of the MOZART-4 chemical transport model, in situ measurements from aircraft (ARCTAS and ARCPAC campaigns) and remote measurements from ground-based Fourier Transform InfraRed (FTIR) and IASI spectrometers. First, a brief description of the model and measurements is given, followed by an evaluation of the model using observations of $\mathrm{O}_{3}$ and $\mathrm{HNO}_{3}$ during the campaigns in Sect. 3. In Sect. 4, the source attribution and their partitioning derived from the "tagging method" are presented. In Sect. 5, tropospheric observations of $\mathrm{O}_{3}$ from FTIR instruments, at the Thule (Greenland) and Eureka (Canada) polar sites, and from the IASI satellite during the aircraft campaigns are discussed in comparison with 
MOZART-4 results. We also use IASI observations to further investigate the capability of the instrument to observe the sources of pollution and the transport into the Arctic. Conclusions are given in Sect. 6 .

\section{Model and measurements}

\subsection{MOZART-4 model description}

For this paper, model simulations were performed with the MOZART-4 global 3-D chemical transport model (Emmons et al., 2010a). It was driven by offline meteorological fields from the National Centers for Environmental Prediction (NCEP) Global Forecast System (GFS), with a horizontal resolution of $1.4^{\circ} \times 1.4^{\circ}$ (approximately $140 \mathrm{~km}$ ) with 64 levels from the surface up to $2 \mathrm{hPa}$. MOZART-4 was run with its standard chemical mechanism, including 97 species and approximately 200 reactions (Emmons et al., 2010a). As described in detail in Emmons et al. (2010a), MOZART-4 does not have a complete chemistry in the stratosphere. For specifying long-lived species in the stratosphere (including $\mathrm{O}_{3}, \mathrm{CO}, \mathrm{CH}_{4}, \mathrm{HNO}_{3}, \mathrm{NO}_{\mathrm{x}}$ ), it uses zonal mean climatological values above $50 \mathrm{hPa}$, coming from MOZART- 3 simulations (Kinnison et al., 2007), and then it constrains the mixing ratios by relaxation toward the climatology down to the tropopause. MOZART-4 is also not complete for the troposphere since it does not include halogen chemistry. Our model simulations, covering the period April 2008July 2008, have been initialized by model simulations at $2.8^{\circ} \times 2.8^{\circ}$ starting July 2007 with 42 levels in the vertical. MOZART-4 simulations of $\mathrm{O}_{3}$ and related tracers have been previously compared to numerous in situ observations and used to track the intercontinental transport of pollution (e.g., Emmons et al., 2010b; Pfister et al., 2006, 2008).

The anthropogenic emissions used here are taken from the 2006 inventory of Zhang et al. (2009). This emission inventory is built upon the INTEX-B inventory with additional data from other inventories to obtain global emissions (see http://www.cgrer.uiowa.edu/arctas/emission.html for more information). These emissions are constant in time, with no monthly variation. The emissions for VOCs are only available as total VOCs, so speciation to the MOZART4 VOCs was based on the VOC speciation of the RETRO emissions inventory, as in Lamarque et al. (2010). The fire emissions were calculated using the global Fire INventory from NCAR (FINN) version 1 (Wiedinmyer et al., 2011). Emissions for individual fires, based on daily MODIS fire counts, were calculated and then gridded to the simulation resolution (Wiedinmyer et al., 2006, 2011). Aircraft emissions of $\mathrm{NO}, \mathrm{CO}$ and $\mathrm{SO}_{2}$ from general aviation and military traffic for 1999 are also taken into account (Emmons et al., 2010a). Other natural emissions, for example, NO from soil and lightning are also included in the standard MOZART-4 scheme. Soil NO emissions are a combination of interac- tive natural emissions (Yienger and Levy, 1995) and fertilizer use (Bouwman et al., 2002). The lightning parameterization is based on cloud-top height (Emmons et al., 2010a). In MOZART-4, $\mathrm{NO}_{\mathrm{x}}$ is emitted as $\mathrm{NO}$ and the partitioning between $\mathrm{NO}$ and $\mathrm{NO}_{2}$ is calculated explicitly in the chemistry.

Global and regional model $\mathrm{NO}_{\mathrm{x}}$ emissions for the 1-19 April 2008 and the 18 June-13 July periods are summarized in Table 1. Model $\mathrm{NO}_{\mathrm{x}}$ emissions using these inventories for these two periods are shown in Fig. 1. The highest $\mathrm{NO}_{\mathrm{x}}$ surface emissions for April 2008 are due to particularly intense biomass burning over Southeast Asia and Southern Russia, where values of $4 \times 10^{-10} \mathrm{~kg}\left(\mathrm{NO}_{\mathrm{x}}\right) \mathrm{m}^{-2} \mathrm{~s}^{-1}$ are introduced in the model. For summer 2008, some fires are observed over Southern Russia, over California and over central Canada.

\subsection{Aircraft, ground-based FTIR and satellite data}

The ARCTAS mission acquired measurements using three research aircrafts, including the NASA DC- 8 with a detailed chemical payload (Jacob et al., 2010). The spring ARCTASA deployment took place from 1 to 19 April 2008. The DC8 was based in Fairbanks, Alaska, but made two overnight flights to Thule, Greenland and Iqaluit, Nunavut. The summer ARCTAS-B deployment took place from 26 June to 13 July 2008. The DC-8 had a two-night stay in Thule to overfly Summit, Greenland and focused on sampling North American biomass burning outflow. The summer ARCTAS-CARB deployment (18-24 June) was focused on California air quality, targeting wildfires in Northern California and urban and agricultural pollution. The ARCPAC airborne field experiment, which took place in Alaska from 1 to 23 April 2008, was coordinated with the POLARCAT activity and focused on the factors driving the radiative forcing by aerosols and tropospheric ozone in the Arctic (Brock et al., 2011). It used a NOAA WP-3D aircraft, with extensive in situ instrumentation for aerosols, ozone and related species and with flights coordinated with the spring ARCTAS aircraft mission concurrently based in Fairbanks.

Here, we use the $\mathrm{O}_{3}$ and $\mathrm{HNO}_{3}$ data from the NASA DC8 aircraft to study the long-range transport of pollution from mid-latitudes into the Arctic. We consider all flights from the three deployments (ARCTAS-A, ARCTAS-B and ARCTASCARB) of the ARCTAS mission, covering two periods: the spring period (1-19 April 2008) and the summer period (18 June-13 July). We also consider data from all flights of the NOAA WP-3D ARCPAC mission (1-23 April 2008) during the spring period. Measurements of $\mathrm{O}_{3}$ and $\mathrm{HNO}_{3}$ were made respectively by $\mathrm{NO}$ chemiluminescence and chemical ionization mass spectrometry (CIMS) aboard the DC-8 and the WP-3D aircrafts (Weinheimer et al., 1994; Ryerson et al., 1998; Crounse et al., 2009; Huey at al., 2004; Brock et al., 2011 and references therein). The observations have an estimated uncertainty of $0.05 \mathrm{ppbv}+4 \%$ for $\mathrm{O}_{3}$ (Ryerson et al., 1998 ), of $25 \% \pm 0.15$ ppbv for WP-3D $\mathrm{HNO}_{3}$ (Huey at al., 
Table 1. Global and regional $\mathrm{NO}_{\mathrm{x}}$ emission sources used in MOZART-4 simulations for the ARCTAS spring (1-19 April) and summer (18 June-13 July 2008) campaign periods.

\begin{tabular}{lcc}
\hline Sources & \multicolumn{2}{c}{$\mathrm{NO}_{\mathrm{x}}$ emissions $(\mathrm{Tg})$} \\
\cline { 2 - 3 } & Spring period (19 days) & Summer period (26 days) \\
\hline Anthropogenic Total & 3.73 & 5.11 \\
\hline North America $\left(180-45^{\circ} \mathrm{W}, 20-90^{\circ} \mathrm{N}\right)$ & 0.76 & 1.05 \\
Europe $\left(15^{\circ} \mathrm{W}-60^{\circ} \mathrm{E}, 30-90^{\circ} \mathrm{N}\right)$ & 1.22 & 1.67 \\
Asia $\left(60-180^{\circ} \mathrm{E}, 0-90^{\circ} \mathrm{N}\right)$ & 1.22 & 1.68 \\
\hline Biomass burning Total & 1.66 & 1.14 \\
\hline USA $\left(130-60^{\circ} \mathrm{W}, 25-50^{\circ} \mathrm{N}\right)$ & 0.021 & 0.051 \\
Canada $\left(170-50^{\circ} \mathrm{W}, 50-90^{\circ} \mathrm{N}\right)$ & 0.0013 & 0.050 \\
North Asia $\left(30-180^{\circ} \mathrm{E}, 40-70^{\circ} \mathrm{N}\right)$ & 0.62 & 0.49 \\
South Asia $\left(60-180^{\circ} \mathrm{E}, 0-40^{\circ} \mathrm{N}\right)$ & 0.92 & 0.017 \\
\hline Lightning Total $[\mathrm{Tg}-\mathrm{N}]$ & 0.29 & 0.41 \\
\hline Other sources $(\mathrm{Soil} \mathrm{emission}+$ aircraft) & 0.60 & 0.94 \\
\hline TOTAL & 6.28 & 7.60 \\
\hline
\end{tabular}

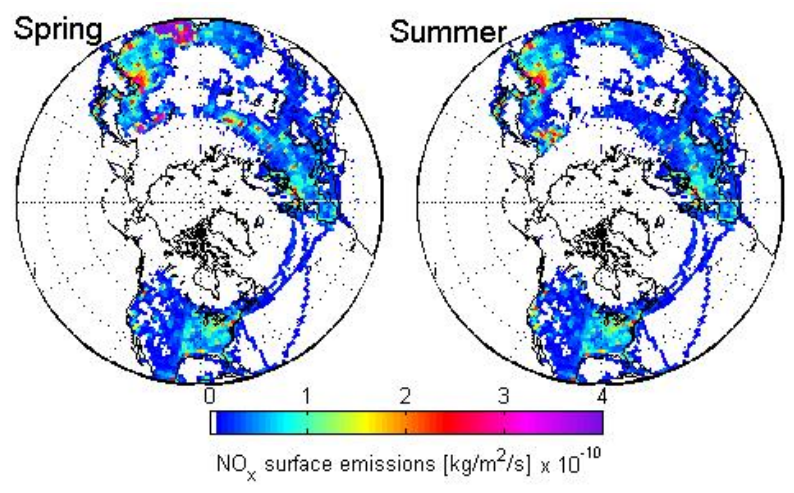

Fig. 1. Model $\mathrm{NO}_{\mathrm{x}}$ surface emission fluxes during the ARCTAS spring (1-19 April 2008) and the ARCTAS summer (18 June-13 July 2008) campaign periods.

2004), and of $30 \% \pm 30$ pptv for DC- $8 \mathrm{HNO}_{3}$ (Crounse et al., 2006). As described in Brock et al. (2011), instrument comparisons were performed during separate coordinated flights with the NASA DC-8 and the NOAA WP-3D at the same altitude. Results from the comparison can be found at: http://www-air.larc.nasa.gov/TAbMEP2_polarcat.html. The preliminary POLARCAT $\mathrm{O}_{3}$ assessment report estimates a deduced relative bias between the DC- 8 and WP-3D instruments as the sum of: $0.904(\mathrm{ppb})+0.0480 * \mathrm{DC}-8 \mathrm{O}_{3}$ (ppb) with the DC- 8 taken as an arbitrary reference. The comparison between DC-8 and WP-3D instruments for $\mathrm{HNO}_{3}$ can be found at: http://www-air.larc.nasa.gov/cgi-bin/ic2008r. The ambient levels reported by the DC- 8 instrument during the comparison period were within the reported imprecision of the WP-3D instrument making it difficult to assess any bias for $\mathrm{HNO}_{3}$ between these instruments.

For comparisons between MOZART-4 model simulations and aircraft observations, the MOZART-4 model results from 6-h window averages are sampled along the flight track at the same location, altitude and time of the observations, making use of 1-min average aircraft measurements.

Additional independent comparisons of $\mathrm{O}_{3}$ model results with ground-based FTIR solar absorption measurements are also performed for two sites: Eureka $\left(80^{\circ} \mathrm{N}, 86^{\circ} \mathrm{W}\right)$ and Thule $\left(77^{\circ} \mathrm{N}, 69^{\circ} \mathrm{W}\right)$. These measurements were made with Bruker 125 HR FTIR spectrometers, operated in the framework of the Network for the Detection of Atmospheric Composition Change (NDACC) (Kurylo, 1991; Kurylo and Zander, 2000). The retrieval of trace gas profiles from the FTIR spectra are performed using the SFIT2 algorithm, a solar transmittance and retrieval model based on the optimal estimation method (OEM), and a specific set of microwindows (Batchelor et al., 2009; Hannigan et al., 2009; Lindemaier et al., 2010). The typical total error on the retrieved $\mathrm{O}_{3}$ total columns is $\sim 10 \%$ (Batchelor et al., 2009). During the aircraft campaign periods, measurements at Thule were only available from 1 to 15 April, while a larger set of measurements at Eureka were made coinciding with the spring and summer campaigns. Typical FTIR averaging kernels, which express the sensitivity of the retrieval to the abundance of the target species within the layers throughout the atmospheric column, are shown in Fig. 2 (left) for the retrieved tropospheric layers and for the tropospheric and total columns. The analysis of the averaging kernels indicates that most of the retrieved information comes from the measurements. 

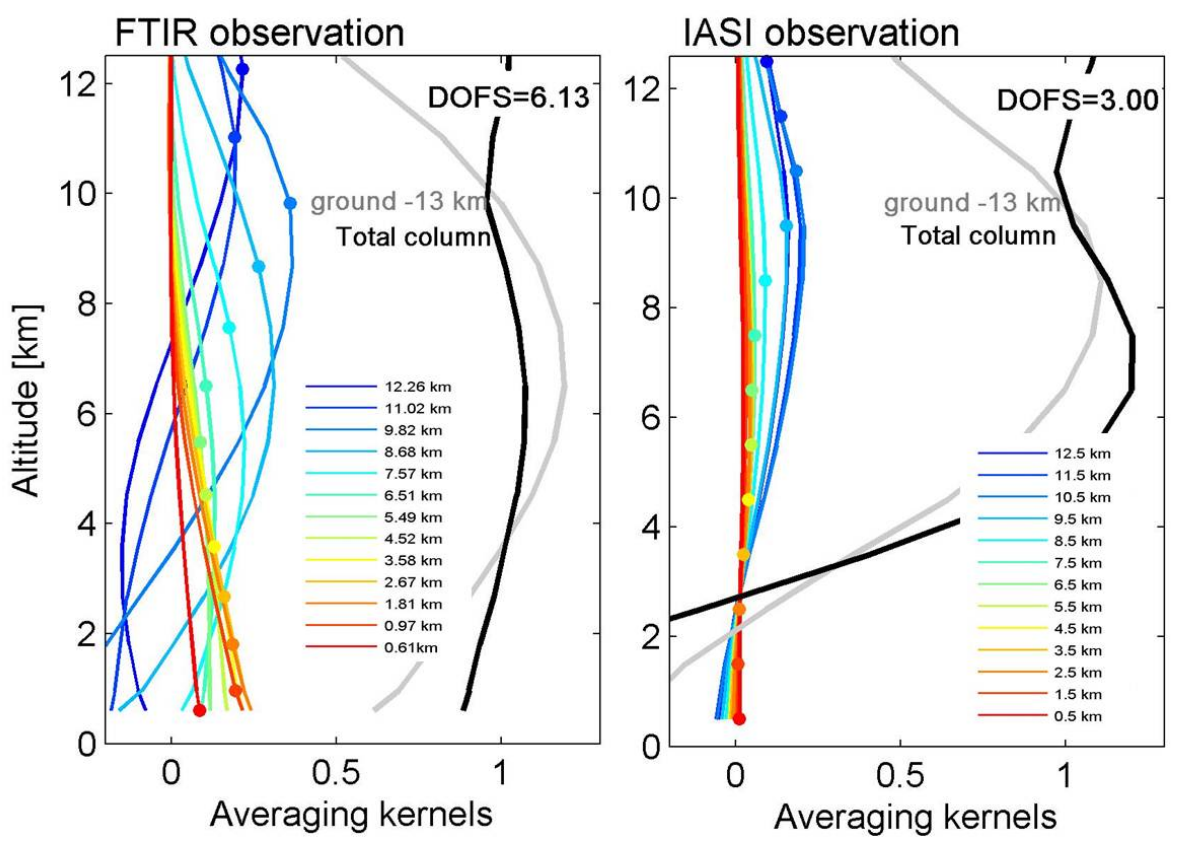

Fig. 2. Typical FTIR (left) and IASI (right) $\mathrm{O}_{3}$ averaging kernels in partial column units (molecules $\mathrm{cm}^{-2} / \mathrm{molecules} \mathrm{cm}^{-2}$ ) for different retrieved layers for $\mathrm{O}_{3}$ at Eureka (10 July).

They reveal a DOFS (Degrees Of Freedom for Signal, which represents the pieces of independent information contained in the measurement) ranging from about 5.8 to 6.5 over the spring and the summer campaigns, with a maximum sensitivity around $6 \mathrm{~km}$.

$\mathrm{O}_{3}$ profiles from the IASI infrared sounder are also used here for further comparison with MOZART-4 results. IASI measures the thermal infrared emission of the Earthatmosphere system between 645 and $2760 \mathrm{~cm}^{-1}$ with a field of view of $2 \times 2$ circular pixels on the ground, each of $12 \mathrm{~km}$ diameter at nadir. The IASI measurements are taken at nadir every $50 \mathrm{~km}$ along the track of the satellite and they are also taken across-track over a swath width of $2200 \mathrm{~km}$. IASI offers in its standard observing mode a global coverage twice a day with overpass times at 09:30 and 21:30 mean local solar time. IASI measures concentrations of several gasphase species including $\mathrm{O}_{3}, \mathrm{HNO}_{3}, \mathrm{CO}$, and detects fires and associated smoke plumes (Clerbaux et al., 2009; Wespes et al., 2009; Coheur et al., 2009; Turquety et al., 2009; Pommier et al., 2010). $\mathrm{O}_{3}$ profiles are retrieved with the FORLI-O $_{3}$ (Fast Operational/Optimal Retrievals on Layers for IASI) processing chain set up by ULB/LATMOS groups (Clerbaux et al., 2009; Dufour et al., 2011). It provides profiles on 39 layers from the surface up to $39 \mathrm{~km}$, relying on a fast radiative transfer and retrieval methodology, based on the Optimal Estimation Method (Rodgers, 2000), which has been developed initially for the retrieval of $\mathrm{HNO}_{3}$ from IASI (Wespes et al., 2009). As described in Scannell et al. (2011), the a priori information (a priori profile and a priori covariance matrix) used for the retrieval of $\mathrm{O}_{3}$ is built from the Logan/Labow/McPeters climatology (McPeters et al., 2007) which is a combination of data from the Stratospheric Aerosol and Gas Experiment II (SAGE II; 19882001), the Microwave Limb Sounder (MLS; 1991-1999) and data from balloon sondes (1988-2002) to represent the best approximation of the atmospheric state. Note that a single $\mathrm{O}_{3}$ a priori profile and variance-covariance matrix are used. The FORLI-O ${ }_{3}$ product is currently under validation, including polar regions (Scannell et al., 2011; Dufour et al., 2011; Anton et al., 2011). The total error on the retrieval ranges between $\sim 5 \%$ (Northern latitudes) and $\sim 15 \%$ (equatorial latitudes) for the surface- $300 \mathrm{hPa}$ column. Only daytime $\mathrm{O}_{3}$ IASI observations with a good spectral fit (RMS of the spectral residual lower than $4 \times 10^{-8} \mathrm{~W} \mathrm{~cm}^{-2} \mathrm{sr} \mathrm{cm}^{-1}$ ) have been used in this study. The reason for only considering the daytime IASI observations relies on a better vertical sensitivity to the troposphere associated with a higher surface temperature and a higher thermal contrast (Clerbaux et al., 2009; Boynard et al., 2009). The cloud information from the operational processing is further used for filtering the observations, and only scenes with cloud coverage below $25 \%$ are analyzed (Clerbaux et al., 2009). An example of typical FORLI-O ${ }_{3}$ averaging kernel functions for polar observation with a DOFS of 3 is represented on the right panel of Fig. 2. The averaging kernels show a maximum sensitivity at around $8 \mathrm{~km}$ with a sharp decrease of sensitivity down to the surface, which is inherent to nadir thermal IR sounding in cases of low surface temperature and low thermal contrast. This decrease of sensitivity, below around $4 \mathrm{~km}$, indicates that the retrieved information principally comes from the a priori at 
these altitudes. Taken globally, the DOFS ranges from $\sim 2.5$ in cold polar regions to $\sim 3.5$ at mid-latitudes and up to $\sim 4.5$ in hot tropical region, with a maximum of sensitivity peaking around $6-8 \mathrm{~km}$ altitude for almost all situations. For comparisons with MOZART-4 model simulations, the IASI retrievals are averaged over the MOZART grid and over the 6-h window of the MOZART-4 outputs.

When comparing model profiles with trace gas retrievals from remote sounders, the high resolution modeled layers must be smoothed using the averaging kernels (A) to be meaningfully compared to the observations. The derived

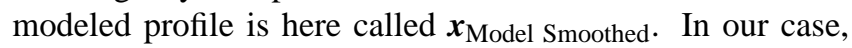
the MOZART-4 profiles were firstly vertically interpolated to the pressure levels of the a priori profiles $\left(\boldsymbol{x}_{\mathrm{a}}\right)$ used in the retrieval algorithms. Then the smoothing of the model profiles $\left(x_{\text {Model }}\right)$ to the lower vertical resolution of the observations (ground-based FTIR or IASI) was performed following (Rodgers, 2000):

$\boldsymbol{x}_{\text {Model Smoothed }}=\boldsymbol{x}_{\mathrm{a}}+\mathbf{A}\left(\boldsymbol{x}_{\text {Model }}-\boldsymbol{x}_{\mathrm{a}}\right)$

In order to take into account the specific scene of each observation, the averaging kernels of the different observations contained in each MOZART grid have been considered to smooth the gridded MOZART profile.

$\mathrm{HNO}_{3}$ measurements from FTIR and IASI instruments could not be used here due to a weak sensitivity of these instruments to this compound in the troposphere (Vigouroux et al., 2006; Wespes et al., 2009).

\section{$\begin{array}{lll}3 & \mathrm{O}_{3}\end{array}$ and $\mathrm{HNO}_{3}$ observations and model evaluation along the aircraft flight tracks}

Observed and simulated volume mixing ratio (VMR) of $\mathrm{O}_{3}$ and $\mathrm{HNO}_{3}$ along the flight tracks of ARCPAC, ARCTAS-A, -CARB and -B are shown in Fig. 3. The flight altitudes extend from 0 to $7 \mathrm{~km}$ for ARCPAC and from 0 to $12 \mathrm{~km}$ for ARCTAS. The highest values observed north of $50^{\circ} \mathrm{N}$ both for $\mathrm{O}_{3}$ (red hotspots above $120 \mathrm{ppbv}$ in Fig. 3) and $\mathrm{HNO}_{3}$ (above 0.3 ppbv), principally during ARCTAS, correspond to observations made above $8 \mathrm{~km}$, and show influences from stratospheric air masses. The stratospheric air masses can be diagnosed as $\left[\mathrm{O}_{3}\right] /[\mathrm{CO}]>1.25$ (Hudman et al., 2007). Excluding these, we observe, along the ARCPAC flights, concentrations ranging from 20 to $90 \mathrm{ppbv}$ for $\mathrm{O}_{3}$, while they range from 0.01 to $0.12 \mathrm{ppbv}$ for $\mathrm{HNO}_{3}$. For ARCTAS, $\mathrm{O}_{3}$ measurements range from 20 to $120 \mathrm{ppbv}$ and $\mathrm{HNO}_{3}$ measurements reach $14 \mathrm{ppb}$. The maxima for $\mathrm{HNO}_{3}$ are observed over California during ARCTAS-CARB and they can be attributed to fires and urban pollution, as further discussed in Sect. 4.1. These observations are broadly consistent with previous measurements in urban plumes (e.g., Emmons et al., 2000; Bey et al., 2001; Neuman et al., 2006).

Figure 4 presents the vertical distribution, averaged over $0.5 \mathrm{~km}$ layers, of the ARCPAC and the ARCTAS aircraft ob- servations, along with the model values interpolated to the flight tracks. The differences relative to the observations, expressed as a percentage, are shown on the right panels for each campaign. Vertical distributions of observations and model results show an increase of $\mathrm{O}_{3}$ mixing ratios from around $50 \mathrm{ppbv}$ at the surface to $90 \mathrm{ppbv}$ in the upper troposphere. It is followed by a sharp increase above $8 \mathrm{~km}$ for ARCTAS-A and above $11 \mathrm{~km}$ for ARCTAS-B, reflecting the influence of stratospheric air. The latter is also observed in the vertical distributions of $\mathrm{HNO}_{3}$. During the ARCTAS-CARB and the ARCTAS-B campaigns, a maximum for $\mathrm{HNO}_{3}$ near the surface, followed by a decrease of VMR with altitude to around $5 \mathrm{~km}$ is observed. The highest values near the surface are principally representative of fresh plumes from anthropogenic pollution in addition to fires from California, for the ARCTAS-CARB, and from Canada, for the ARCTAS-B aircraft observations.

The aircraft data set shows the largest variability in the upper troposphere - lower stratosphere during ARCTAS-A and ARCTAS-B and in the boundary layer for the $\mathrm{HNO}_{3}$ measurements during ARCTAS-CARB and ARCTAS-B (horizontal bars in Fig. 4). We also find a larger relative variability associated with the $\mathrm{HNO}_{3}$ observations (50-200\%) than those associated with the $\mathrm{O}_{3}$ observations $(0-60 \%)$ consistent with the much shorter lifetime of $\mathrm{HNO}_{3}$ and to a larger relative uncertainty in the $\mathrm{HNO}_{3}$ observations (Sect. 2.2). Relative to the aircraft measurements, the model underestimates $\mathrm{O}_{3}$ and $\mathrm{HNO}_{3}$ concentrations by $5-15 \%$ and $3-35 \%$ for overall campaign averages, respectively. The relative differences between observations and model are larger for $\mathrm{HNO}_{3}$ (around -80 to $150 \%$ ) than for $\mathrm{O}_{3}$ ( -40 to $50 \%$ ), possibly explained by the larger variability associated with the $\mathrm{HNO}_{3}$ observations that cannot be captured with the relatively coarse model resolution. The high correlation coefficients $(R)$ between model and observations, principally for the ARCTAS data sets probably illustrate the large vertical gradient sampled during the aircraft flight tracks and the performance of the model for reproducing the variability of observations in space and time. The lower value of $R$ for ARCPAC data, particularly for $\mathrm{HNO}_{3}$, could result from the lower vertical gradient sampled during the ARCPAC flights, from the long-distance displacement and smearing of plumes from sources into the Alaskan Arctic, inducing larger model error (Fisher et al., 2010; Rastigejev et al., 2009; Tilmes et al., 2011) and from the large relative uncertainty in the $\mathrm{HNO}_{3}$ observations at concentrations below $0.1 \mathrm{ppbv}$.

Figure 5 shows a comparison of $\mathrm{O}_{3}$ and $\mathrm{HNO}_{3}$ aircraft data with MOZART-4 for data representative of the altitude and latitude sampled during the ARCTAS campaign, with the flight altitude plotted on the right axis. In general, the MOZART-4 model reproduces the spatial and temporal variability of observations well. However, some discrepancies can be observed. Extremely low values of $\mathrm{O}_{3}$ in the boundary layer in the Arctic (e.g., flights on 8 and 17 April, Fig. 5) are not reproduced in the model. A likely explanation is the 
(a)
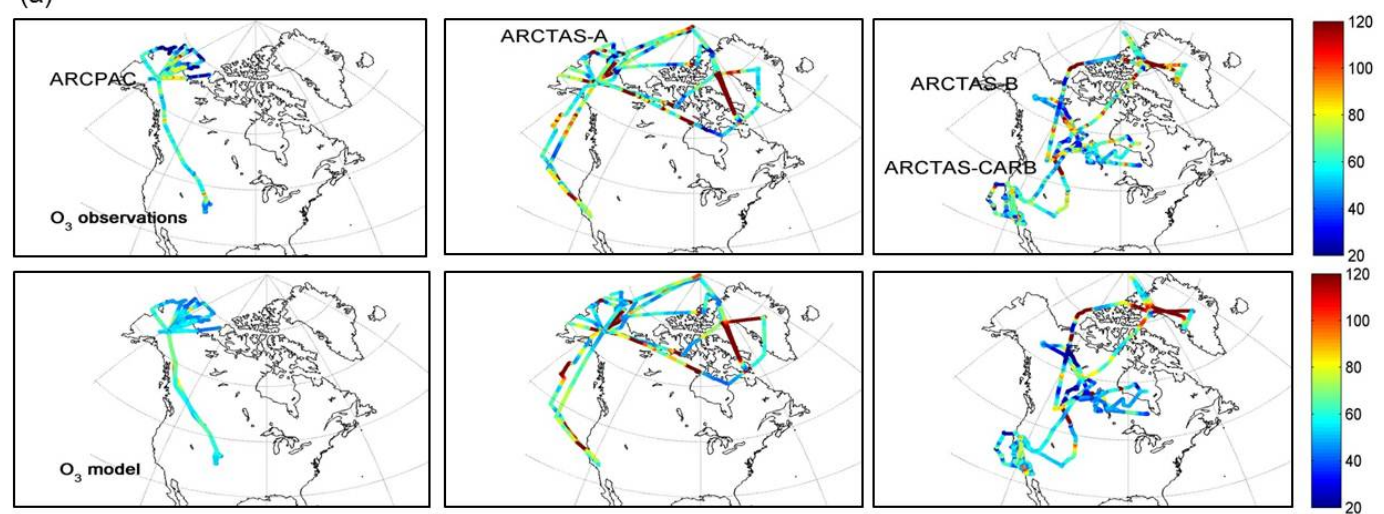

(b)
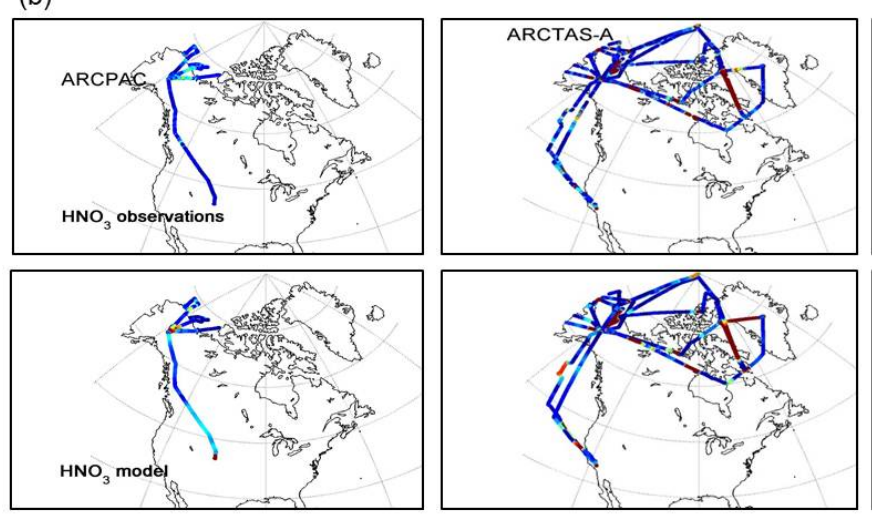

Fig. 3. (a) $\mathrm{O}_{3}$ and (b) $\mathrm{HNO}_{3}$ mixing ratios (ppb) observed during the ARCPAC (3 to 23 April 2008), the ARCTAS-A (1 to 19 April 2008 ) and the ARCTAS summer (18 June to 13 July 2008) campaigns (ARCTAS-CARB and ARCTAS-B) (top panels) compared to model values (bottom panels) sampled along the flight track at the same time, location and altitude of the observations. The flight tracks extend from 0 to $7 \mathrm{~km}$ for ARCPAC, from 0 to $9 \mathrm{~km}$ for ARCTAS-CARB and from 0 to $12 \mathrm{~km}$ for ARCTAS-A and -B.

missing treatment of the halogen chemistry in MOZART-4, in particular, the bromine chemistry that is responsible for the extreme ozone depletion events that occur within the Arctic boundary layer. Underestimation of $\mathrm{HNO}_{3}$ within the Arctic boundary layer is also simultaneously observed with the overestimation of $\mathrm{O}_{3}$. This probably results from the misrepresentation of the wet deposition processes in the Arctic boundary layer in MOZART-4. The fact that MOZART-4 systematically and simultaneously overestimates $\mathrm{O}_{3}$ and underestimates $\mathrm{HNO}_{3}$ within the Arctic boundary layer in April can also be observed in Fig. 4 (lowest $0.5 \mathrm{~km}$ ). Values of around $100 \mathrm{ppbv}$ or higher observed for $\mathrm{O}_{3}$ and higher than $0.5 \mathrm{ppbv}$ for $\mathrm{HNO}_{3}$ along the highest altitude flights (e.g., flights on 8, 9 and 17 April, Fig. 5), related to stratospheric air masses, are largely underestimated in the model. This probably results from the coarse horizontal and vertical resolution of the model results, which dilutes the stratospheric influence, and from the constraint of $\mathrm{O}_{3}$ and $\mathrm{HNO}_{3}$ and other long-lived species to a climatology in the stratosphere in MOZART-4 (see Sect. 2.1). For $\mathrm{HNO}_{3}$, other discrepancies are observed near the surface (between the ground and $2 \mathrm{~km}$ ) for flights on 9, 12 and 17 April (see Fig. 5) at Barrow, with a significant underestimation in the model. This suggests that low-altitude transport or subsidence of $\mathrm{HNO}_{3}$-rich air masses into this region is not well simulated. It is also worth pointing out that most of the variations in both $\mathrm{O}_{3}$ and $\mathrm{HNO}_{3}$ are correlated with the altitude, except for the flight on 13 July near Trinidad Head. This site, which is representative of fresh urban and wildfire plumes in northern California, shows variations that are anti-correlated with the altitude, suggesting fast oxidation of $\mathrm{NO}_{\mathrm{x}}$ to $\mathrm{O}_{3}$ and $\mathrm{HNO}_{3}$ in source regions.

As another measure of the model performance, the ratio $\mathrm{O}_{3} / \mathrm{HNO}_{3}$, can also be compared with that from the aircraft observations. Figure $6 \mathrm{a}$ and $\mathrm{b}$ show the $\mathrm{O}_{3}$ vs. $\mathrm{HNO}_{3}$ plots for both the aircraft observations and the MOZART4 results, with the points colored by the altitude of the observations. For ARCPAC and ARCTAS-A (Fig. 6a, left), the $\left[\mathrm{O}_{3}\right] /\left[\mathrm{HNO}_{3}\right]$ ratios show, on average, values of 321 for the stratospheric-influenced air masses, diagnosed by $\left[\mathrm{O}_{3}\right] /[\mathrm{CO}]$ ratio larger than 1.25 (Hudman et al., 2007), while much higher values are observed in the troposphere $\left(4 \times 10^{3}\right)$. Identically, the ARCTAS-B measurements show a 
(a)

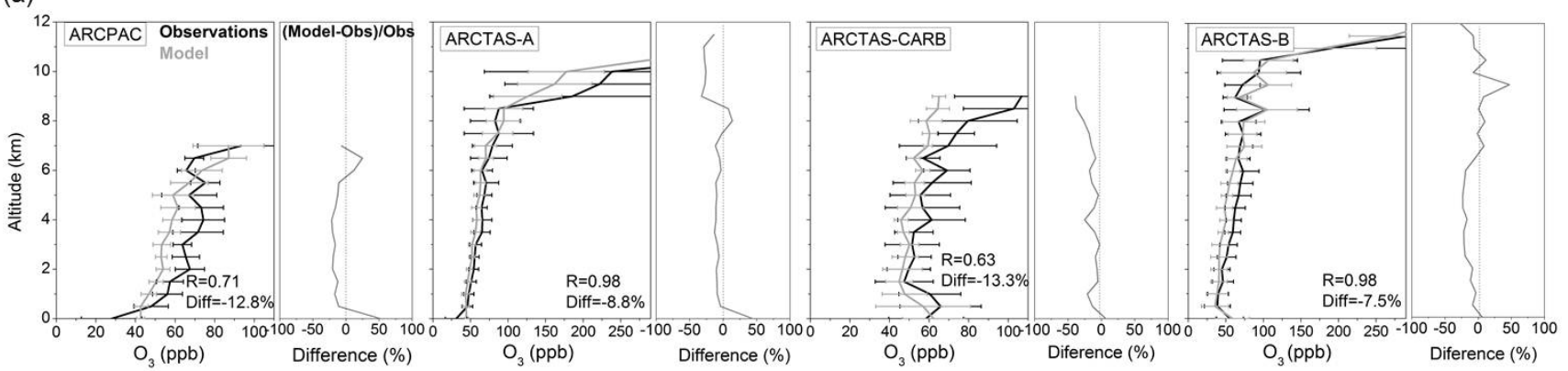

(b)
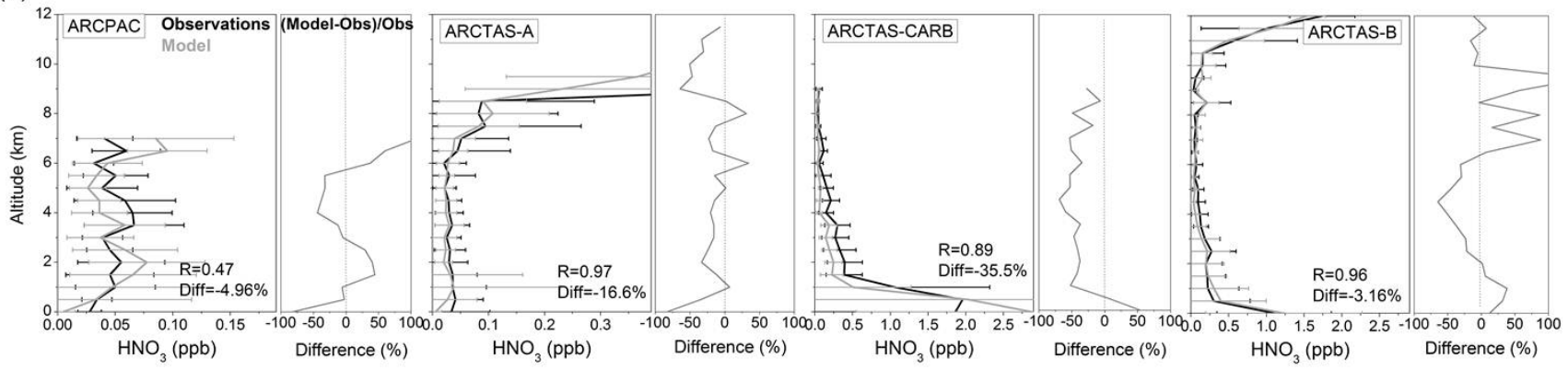

Fig. 4. Vertical distribution of $\mathrm{O}_{3}$ (a) and $\mathrm{HNO}_{3}$ (b) ARCPAC and ARCTAS observations averaged over $0.5 \mathrm{~km}$ altitude, compared to the MOZART-4 model values (from 6-h averages). Horizontal bars represent the variability associated with the observations (3 $\sigma$, where $\sigma$ is the standard deviation). The differences between the observations and the model are shown on the right panels for each campaign. The correlation coefficient and median of the differences are also indicated.

(a)
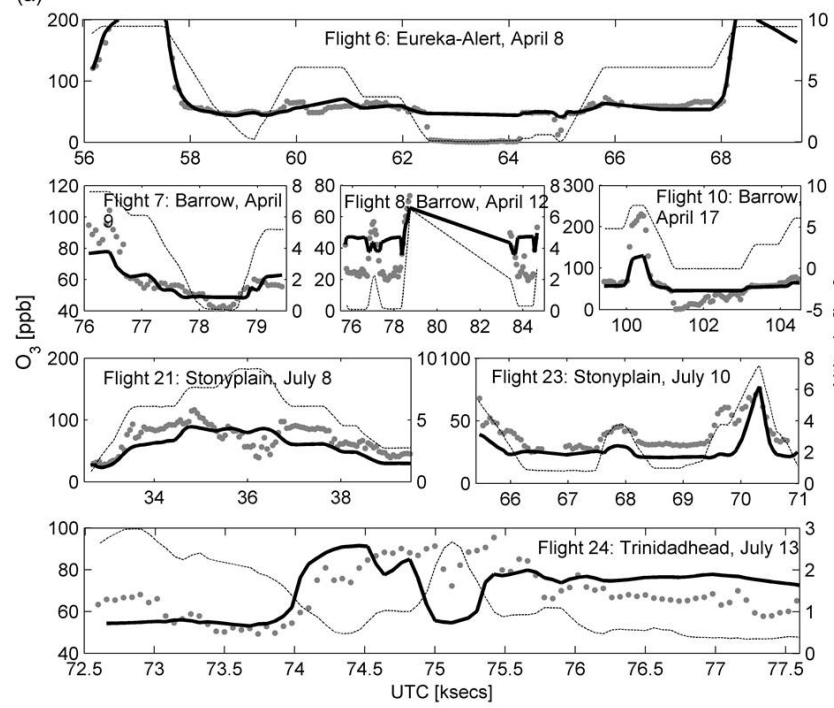

(b)

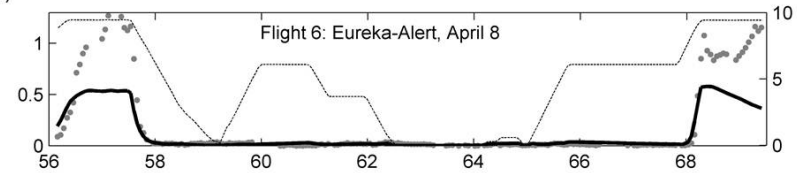

0.1 Flight 7: Barrow, April $^{8}{ }_{\text {. Flight 8: Barrow, April 12 }}^{8}$ Flight 10: Barrow $^{10}$

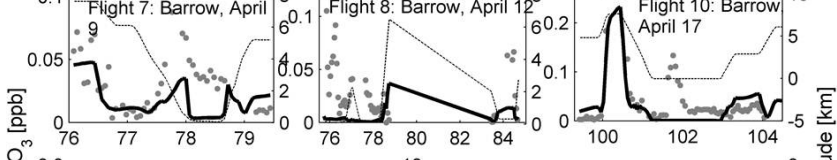

\begin{tabular}{llllllllllllllllll}
\hline$m$ & 76 & 77 & 78 & 79 & 76 & 78 & 80 & 82 & 84 & & 100 & 102 & 104 &
\end{tabular} $\sum_{0.2}^{0.3} \operatorname{Flight~21:~Stonyplain,~July~8~}^{10} 0.1$ Flight23: Stonyplain, July 10 $\left.\triangle\right|_{6} ^{8}$

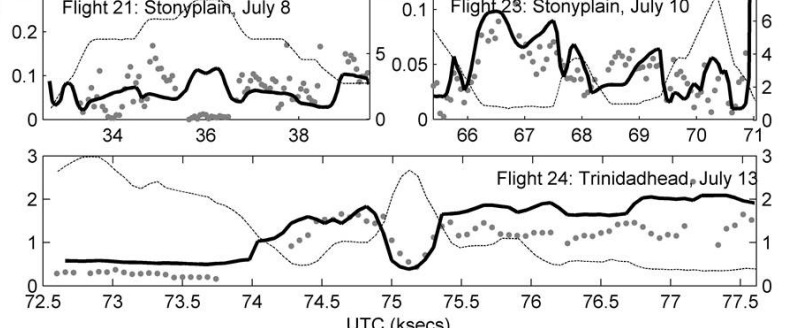

Fig. 5. (a) $\mathrm{O}_{3}$ and (b) $\mathrm{HNO}_{3}$ observations along the track of seven flights representative of the altitude and the latitude sampled during ARCTAS (dark grey dots). The MOZART-4 results (from 6-h averages) are interpolated to the flight path (from 1-min averages) (black line). The flight altitude (thin grey line) is plotted against the right axis.

high $\left[\mathrm{O}_{3}\right] /\left[\mathrm{HNO}_{3}\right]$ ratio $\left(5 \times 10^{3}\right)$ in the free troposphere (not shown), while a ratio of 322 is measured in higher-altitude stratospheric air. However, below $2 \mathrm{~km}$, averaged ratios of 453 and 652, respectively observed during ARCTAS-CARB and ARCTAS-B, with values as low as 8 , indicate weaker ozone production despite the rapid removal of $\mathrm{HNO}_{3}$ by deposition in the boundary layer. These particular lower values characterize fresh air masses from North American urban and 

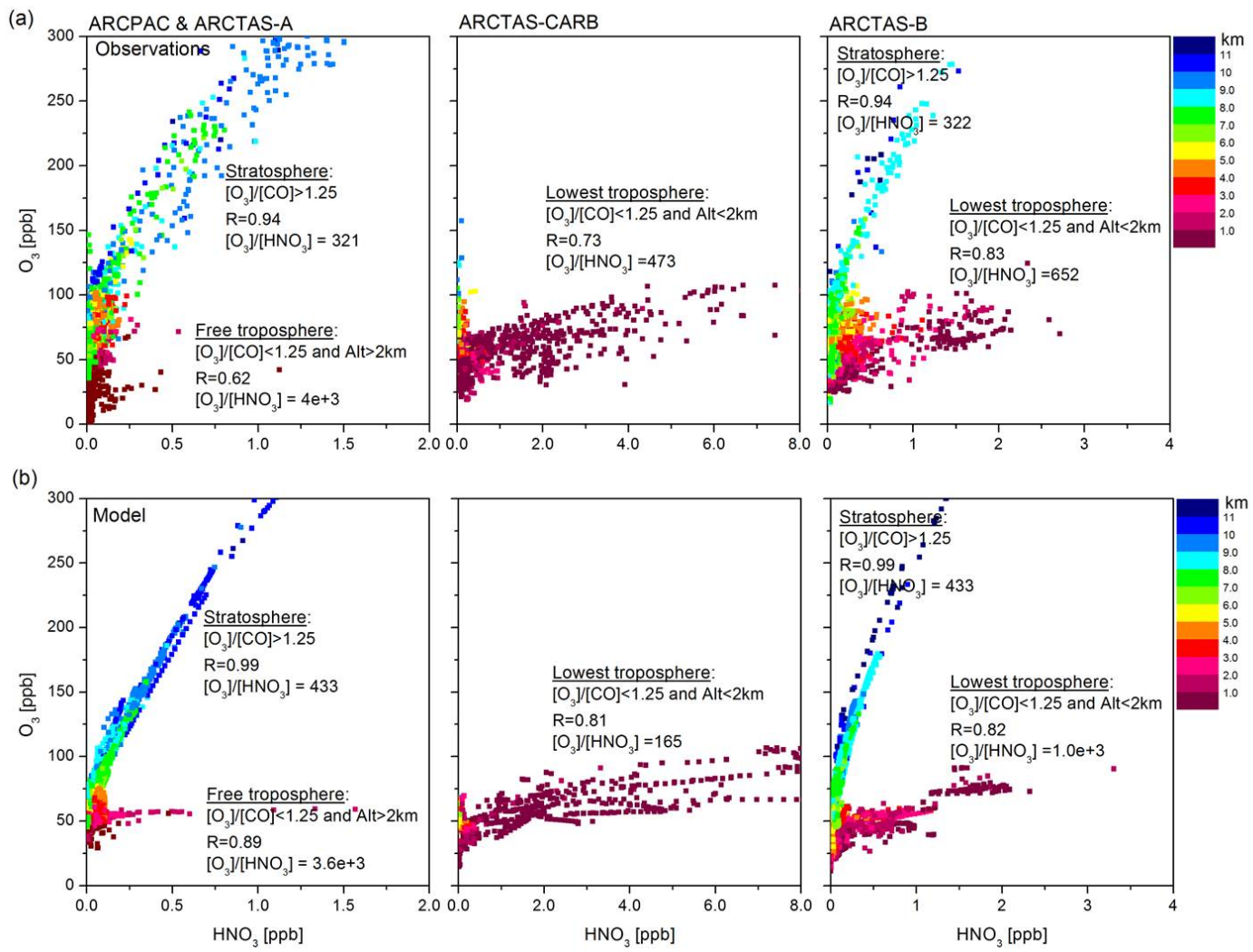

Fig. 6. $\mathrm{O}_{3}$ vs. $\mathrm{HNO}_{3}$ from ARCPAC and ARCTAS-A (left), ARCTAS-CARB (middle) and ARCTAS-B (right) observations (a) compared to the MOZART-4 results (b), with points colored by altitude (in $\mathrm{km}$ ) of observations.

fire emissions (Californian for ARCTAS-CARB and Canadian for ARCTAS-B) corresponding to the highest concentrations of $\mathrm{HNO}_{3}$ illustrated in Fig. 3. This is consistent with earlier studies which point to different $\mathrm{HNO}_{3}$ vs. $\mathrm{O}_{3}$ relationships in the troposphere and in the stratosphere (Bregman et al., 1995; Talbot et al., 1997; Schneider et al., 1999; Neuman et al., 2001; Popp et al., 2009) and which show lower ozone production for air masses with fresh emissions from biomass burning and urban sources than in the free troposphere (Shon et al., 2008). For each specific air mass (fresh pollution, free troposphere or stratosphere-contaminated air mass) and for each data set, we find that $\mathrm{O}_{3} / \mathrm{HNO}_{3}$ ratios and the scatter values are of comparable magnitude between the aircraft observations and the model results. Ratios as low as 8 below $2 \mathrm{~km}$ are well reproduced by the model. The largest differences between the ratios from observations and from model are observed for ARCTAS-CARB. They are driven by a too high formation of $\mathrm{HNO}_{3}$ in the lowermost layer coinciding with an underestimation of $\mathrm{O}_{3}$, as indicated in the Figs. 4 and 5. Some discrepancies in the model are also identified for the stratosphere-contaminated air masses: the ARCTAS-A observations show a relatively broad $\mathrm{O}_{3} / \mathrm{HNO}_{3}$ relationship in comparison with the observations during ARCTAS-B. This presumably reflects different dynamical and photochemical histories of the air masses sampled by the aircraft during the spring, when the stratosphere is dynamically active, and during the summer; characterized by a more uniform photochemical history associated with summertime easterly flow and very little stratospheric wave activity. The differences in the compactness between the modeled and the observed stratospheric $\mathrm{O}_{3} / \mathrm{HNO}_{3}$ relationship can be attributed to the missing stratospheric chemistry and the use of climatological values in the stratosphere (see Sect. 2.1).

\section{Source attribution of $\mathrm{O}_{3}$ and $\mathrm{HNO}_{3}$ Arctic pollution during spring and summer 2008}

In this section, we use MOZART-4 model simulations to diagnose the contributions from the individual sources to the $\mathrm{O}_{3}$ and $\mathrm{HNO}_{3}$ profiles. As described in Lamarque et al. (2005) and Pfister et al. (2006, 2008), the amount of $\mathrm{O}_{3}$ or $\mathrm{HNO}_{3}$ produced from the different $\mathrm{NO}_{\mathrm{x}}$ emission sources is quantified by tagging the $\mathrm{NO}$ emissions. The tagged $\mathrm{NO}$ (from the emissions shown in Fig. 1) is traced through the hydrocarbon and $\mathrm{CO}$ oxidation and through all the odd nitrogen species $\left(\mathrm{HNO}_{3}, \mathrm{PAN}, \mathrm{N}_{2} \mathrm{O}_{5}\right.$, organic nitrates, etc.) to account for recycling of $\mathrm{NO}_{\mathrm{x}}$. The tagged $\mathrm{O}_{3}$ and $\mathrm{HNO}_{3}$ result from the photolysis and oxidation of $\mathrm{NO}_{2}$. As explained in 

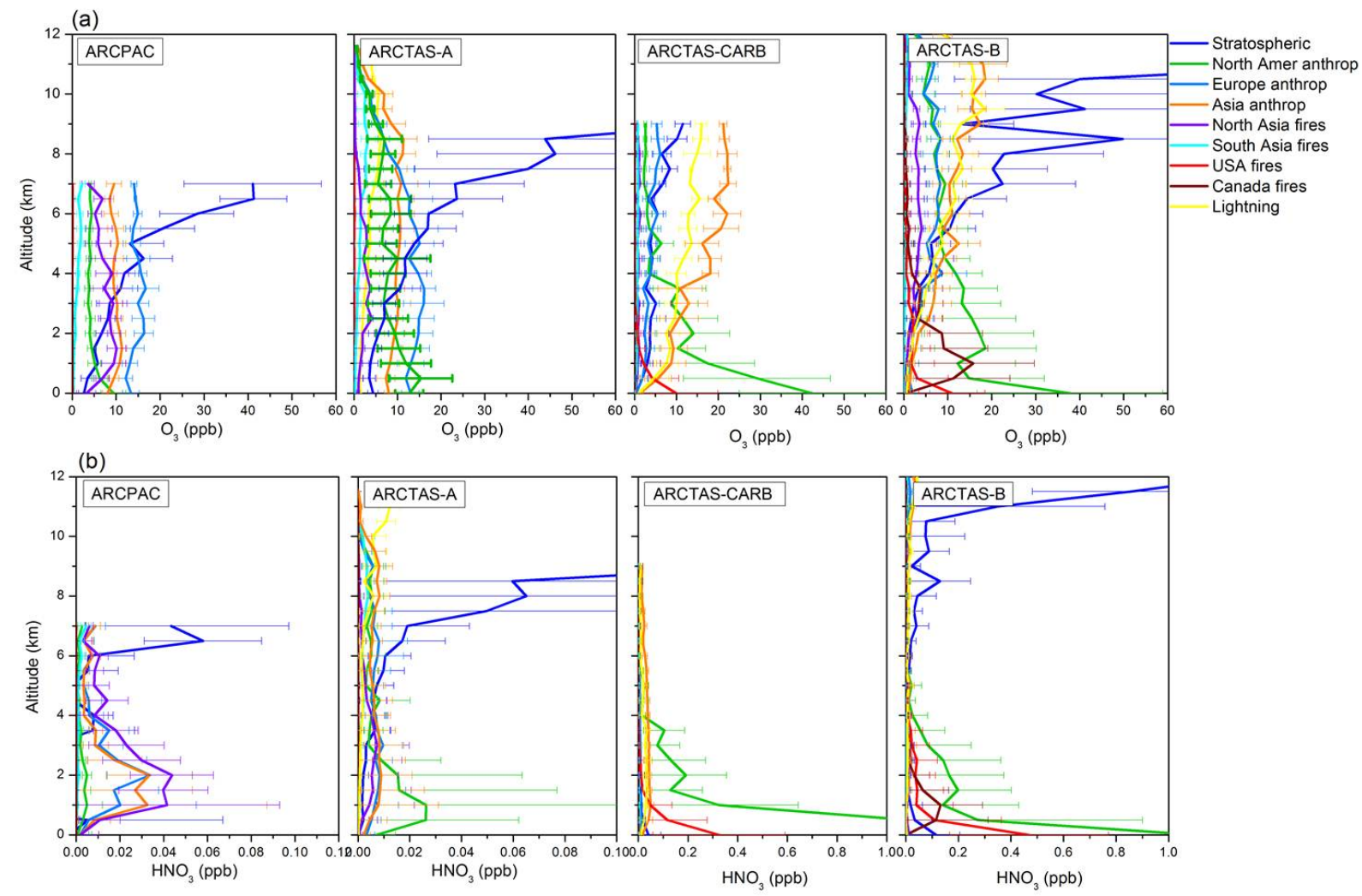

Fig. 7. Vertical distributions of $\mathrm{O}_{3}$ (a) and $\mathrm{HNO}_{3}$ (b) source contributions from MOZART-4 simulations along the flight tracks of the ARCPAC, ARCTAS spring and summer deployments. Data are averaged over $0.5 \mathrm{~km}$ layers and tagged by source type and region. Horizontal bars represent the variability associated with each tagged contribution ( $3 \sigma$, where $\sigma$ is the standard deviation).

Emmons et al. (2010b, 2011), this tagging technique is additive. The sum of the tagged species resulting from each $\mathrm{NO}_{\mathrm{x}}$ source tagged separately reproduces within a few percent the tagged species from the total $\mathrm{NO}_{\mathrm{x}}$ emissions.

\subsection{Partitioning along the aircraft flight tracks}

Figure 7 presents the vertical distributions of $\mathrm{O}_{3}$ and $\mathrm{HNO}_{3}$ concentrations from the MOZART- 4 simulations along the ARCPAC and ARCTAS flight tracks for different source types and regions: stratospheric, anthropogenic (North American, European and Asian), biomass burning (North Asian, South Asian, American and Canadian) and lightningproduced $\mathrm{NO}_{\mathrm{x}}$. For both the ARCPAC and ARCTAS-A campaigns, the mean concentrations of $\mathrm{O}_{3}$ are dominated by European anthropogenic emissions at low altitude. They are followed by North American and Asian anthropogenic contributions for the ARCTAS-A measurements, while the ARCPAC measurements contain large contributions from Asian anthropogenic emissions and from North Asian fires. The latter, which reflects intense Russian fires, is much weaker along the ARCTAS-A than along the ARCPAC flight tracks (Fisher et al., 2010), while the North American anthropogenic contribution is much larger along the ARCTAS-A than along the ARCPAC fight tracks. This reflects the different sampling strategies between the two campaigns (Jacob et al., 2010; Brock et al., 2011). Transport from the stratosphere, which is responsible for a large enhancement of tropospheric ozone in regions of subsidence (Cooper et al., 2002; Liang et al., 2009), is the predominant source above $5 \mathrm{~km}$. It becomes even larger than the sum of the tropospheric contributions above $8 \mathrm{~km}$. During ARCTAS-A, the mean concentrations of $\mathrm{HNO}_{3}$ are dominated at low altitude by the North American anthropogenic contribution, while they are dominated by the Russian fires contribution during ARCPAC. Transport of anthropogenic $\mathrm{HNO}_{3}$ from Europe and from Asia into the Arctic is lower in comparison with that of ozone. This can be explained by a shorter lifetime of $\mathrm{HNO}_{3}$ in the lower layers (a few hours) compared to that of $\mathrm{O}_{3}$ (a few days). Above $5 \mathrm{~km}$, transport from the stratosphere dominates the $\mathrm{HNO}_{3}$ distributions.

During the ARCTAS-CARB and the ARCTAS-B campaigns, the stratospheric influence on tropospheric ozone and nitric acid is less pronounced than during the spring. This is due to weaker stratosphere-troposphere exchanges during the summer but also to the lower latitudes sampled during ARCTAS-CARB. For both $\mathrm{O}_{3}$ and $\mathrm{HNO}_{3}$, the anthropogenic 

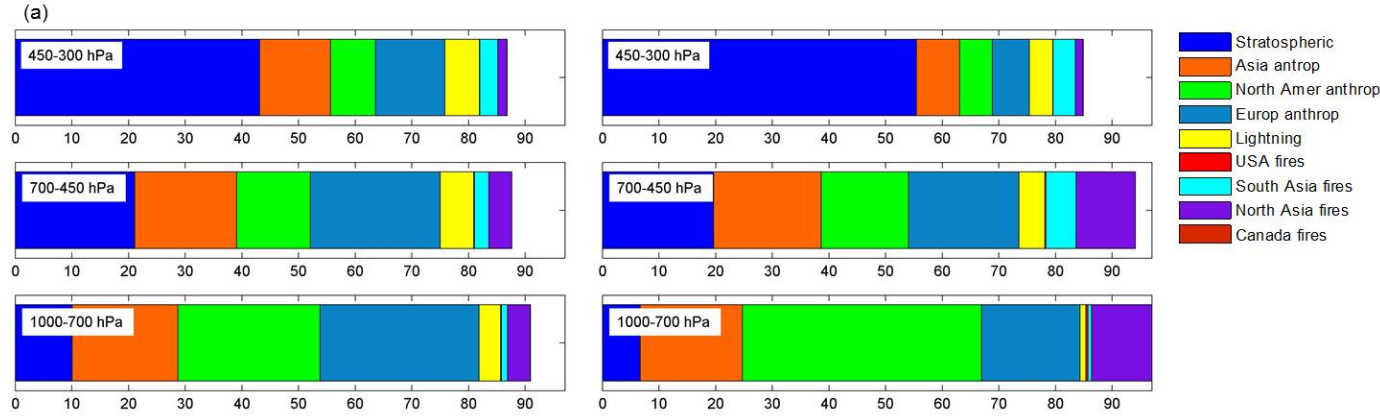

(b)
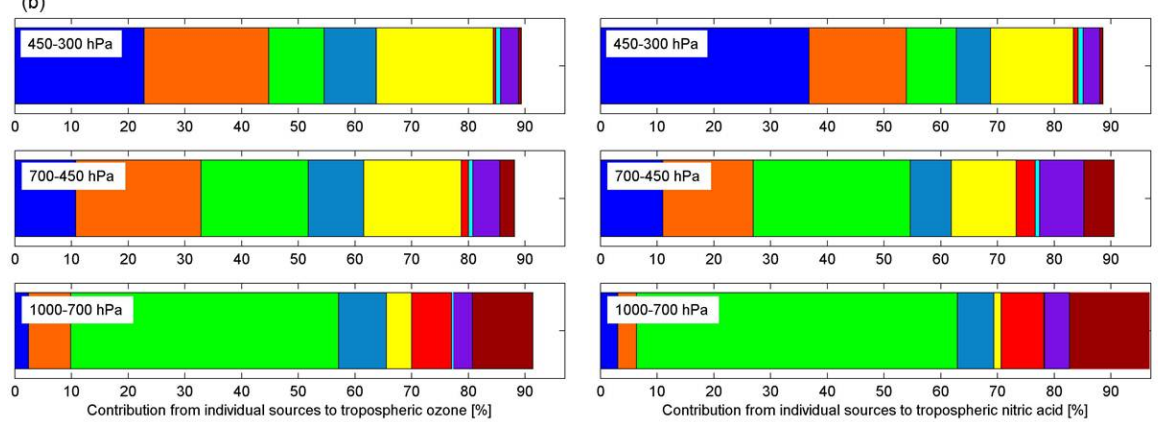

Fig. 8. Partitioning of principal sources of $\mathrm{O}_{3}$ (left) and $\mathrm{HNO}_{3}$ (right) in altitude bands of ground-700 hPa, $700-450 \mathrm{hPa}$ and $450-300 \mathrm{hPa}$ along the ARCTAS spring (a) and summer (b) flight tracks (from 18 June to 13 July), as simulated by MOZART-4, expressed in percentage (\%) of the total.

contribution from North America shows a strong maximum in the lowest layers. Contribution from intense North American fire emissions (California and/or Canada) also shows an important impact on tropospheric ozone in the boundary layer. Evidence for enhanced ozone in boreal fires plumes during the ARCTAS-B campaign has already been reported in Alvarado et al. (2010). We also observe, especially for $\mathrm{O}_{3}$, an increasing contribution in the summer months from lightning-produced $\mathrm{NO}_{\mathrm{x}}$ and from Asian anthropogenic pollution with altitude. The latter is in agreement with the fact that trans-Pacific transport of Asian ozone pollution mainly takes place in the free troposphere where the ozone lifetime is longer (several months) and the winds are strong (Liang et al., 2004; Price et al., 2004). Note also that, based on the model bias relative to the aircraft observations (see Sect. 3), less confidence should be attributed to the quantitative partitioning of the smallest contributors to tropospheric $\mathrm{O}_{3}$ and $\mathrm{HNO}_{3}$.

For both $\mathrm{O}_{3}$ and $\mathrm{HNO}_{3}$ during ARCTAS-A/B, North American anthropogenic pollution sources dominate the variability in the lower troposphere indicating direct lowaltitude transport into the Arctic. The ARCPAC variability is principally determined by the Russian fires emissions and the European anthropogenic pollution. Transport from the stratosphere dominates the variability in the higher altitudes. We also found that the model captures the vertical gradient in the variability (see Sect. 3, Fig. 4) but it underestimates the variability range. When separating data by anthropogenic, stratospheric or fires influence, we found that the underestimation of $\mathrm{O}_{3}$ and $\mathrm{HNO}_{3}$ concentrations in the lower/middle altitudes in the model (see Sect. 3, Fig. 4) is principally dominated by an underrepresentation of local pollution sources (North American anthropogenic pollution, Californian and Canadian fires) during ARCTAS, while it is attributed to an underrepresentation of Russian fire emissions, Asian and European anthropogenic pollution during ARCPAC. At higher altitudes, for the ARCPAC, ARCTAS-A/B observations, the underestimation is related to an underrepresentation of the stratospheric influence. The underrepresentation of both modeled concentrations and variability are possibly due to a mix of uncertainties introduced by the coarse grid of the model leading to too much diffusion, problems in the transport of fine-scale plumes in the model, uncertainties in the emissions, possible bias in the $\mathrm{NO}_{\mathrm{y}}$ partitioning, incomplete stratospheric chemistry of MOZART-4 and interpolation of the MOZART-4 results (from 6-h averages) to the flight path (1-min averages).

In order to further illustrate the tagged contributions to tropospheric $\mathrm{O}_{3}$ and $\mathrm{HNO}_{3}$, Fig. 8 represents the partitioning by source type and region over three altitude ranges during the ARCTAS spring and summer campaigns, as simulated by MOZART-4. Differences between total simulated $\mathrm{O}_{3}$ or $\mathrm{HNO}_{3}(100 \%)$ and the sum of tagged contributions are principally due to $\mathrm{NO}_{\mathrm{x}}$ emissions from soils, but also from aircraft and from ships. An interesting feature in Fig. 8 lies in the observation of increasing relative contribution, during 
(a) $\underline{\mathrm{O}}_{3}$ contributions

1-19 April:

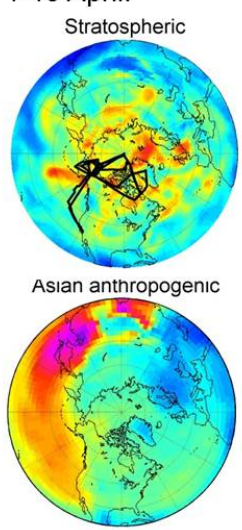

18June-13 July:

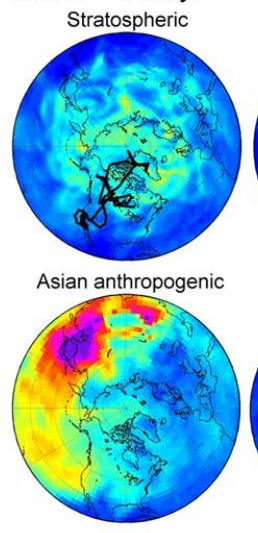

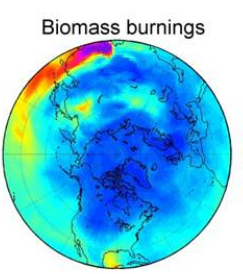
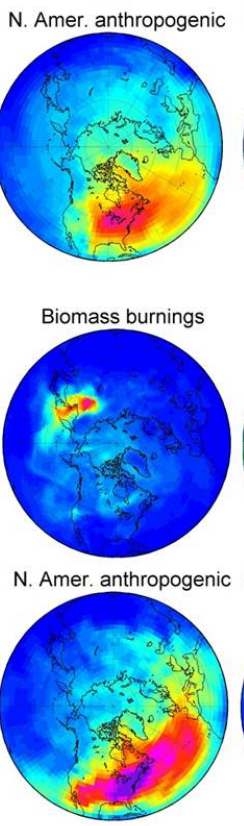
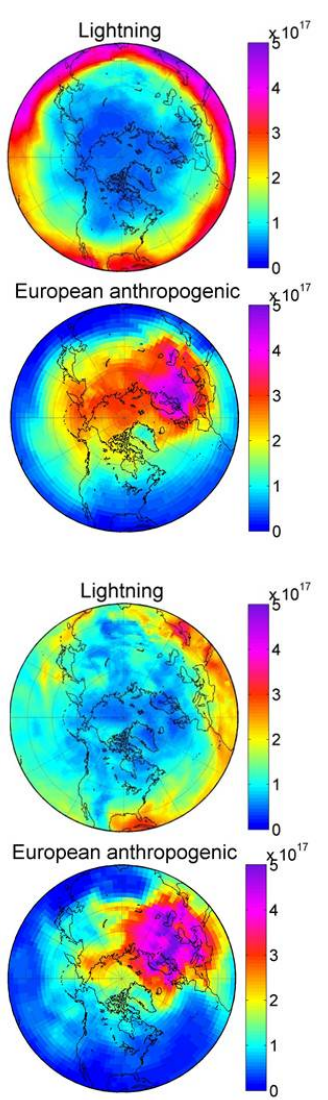

(b) $\underline{\mathrm{HNO}}_{3}$ contributions

1-19 April:

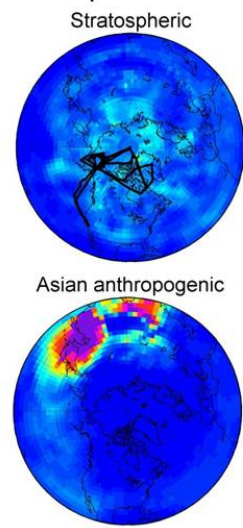

18June-13 July:
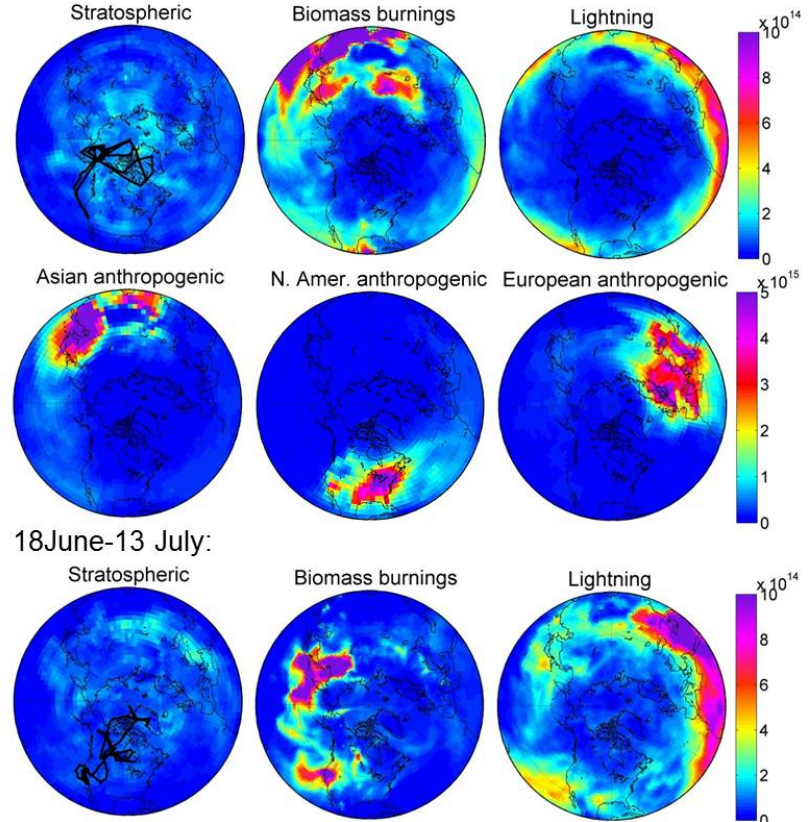

N. Amer. anthropogenic European anthropogenic $x_{5}^{10^{15}}$
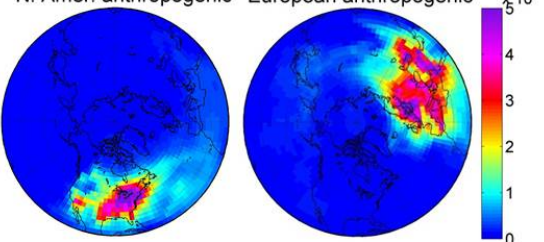

Asian anthropogenic
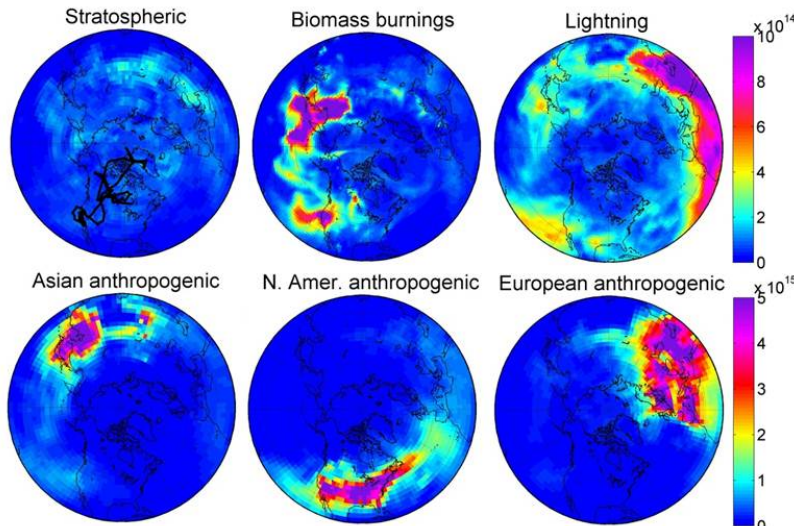

N. Amer. anthropogenic

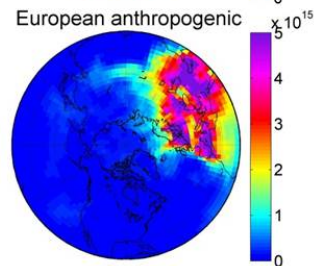

Fig. 9. Principal contributions to $\mathrm{O}_{3}$ (a) and to $\mathrm{HNO}_{3}$ (b) columns (molecules $\mathrm{cm}^{-2}$ ) from the ground to $300 \mathrm{hPa}$ during spring (from 1 to 19 April) and summer (from 18 June to 13 July) ARCTAS campaigns, as simulated by MOZART-4. The flight tracks corresponding to these periods are superimposed in black on the stratospheric contribution plots. Note that the color scales for anthropogenic contributions to $\mathrm{HNO}_{3}$ are different than for the other sources.

the summer, from Asian anthropogenic pollution with altitude for $\mathrm{HNO}_{3}$. The partitioning from that source is larger than from other anthropogenic individual sources (American and European) at higher altitudes, suggesting that this source tends to favor $\mathrm{HNO}_{3}$ in the upper troposphere where it is longer lived (several weeks to a month), making it a candidate for the transport of pollution (Miyazaki et al., 2003; Neuman et al., 2006). It is also worth pointing out that, both during the summer and the spring, the relative partitioning of $\mathrm{O}_{3}$ and of $\mathrm{HNO}_{3}$ are similar along the flight tracks of the aircraft missions, reflecting the chemical link between the two compounds.

\subsection{Partitioning over the Arctic (north of $60^{\circ} \mathrm{N}$ )}

Figure 9 shows simulated spring and summer $\mathrm{O}_{3}$ and $\mathrm{HNO}_{3}$ columns from the ground to $300 \mathrm{hPa}$, of each tagged tracer over the Northern latitudes. Asian, European and North American anthropogenic pollution are of comparable magnitude (reaching $5 \times 10^{17}$ and $5 \times 10^{15}$ molecules $\mathrm{cm}^{-2}$ respectively for $\mathrm{O}_{3}$ and for $\mathrm{HNO}_{3}$ ), but with distinct geographical signatures. Sources in Europe dominate in the European sector of the Arctic over Scandinavia $\left(4 \times 10^{17}\right.$ molecules $\mathrm{cm}^{-2}$ on average for $\left.\mathrm{O}_{3}\right)$ reflecting northward transport, and in the Asian sector of the Arctic $\left(3 \times 10^{17}\right.$ molecules $\mathrm{cm}^{-2}$ on average for $\left.\mathrm{O}_{3}\right)$ through a westerly trans-Siberian transport pathway. Pollution from North America contributes only a small amount to the Arctic pollution (around $1.5 \times 10^{17}$ molecules $\mathrm{cm}^{-2}$ on average for $\mathrm{O}_{3}$ ). According to the ARCPAC observations, the Asian and the European influences dominate the pollution over Alaska. Relative to anthropogenic $\mathrm{O}_{3}$, which shows horizontally smoothed distributions, anthropogenic $\mathrm{HNO}_{3}$ presents a strong horizontal gradient overall the troposphere. This difference is probably due to washout or to the uptake of $\mathrm{HNO}_{3}$ on dust or ice (Querol et al., 2008; Zhang et al., 2008), making it shorter-lived than $\mathrm{O}_{3}$ and therefore, less available for transport into the Arctic. 
(a) $\underline{\mathrm{O}}_{3}$ contributions
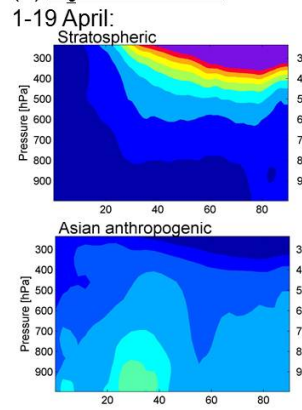

18June-13 July:
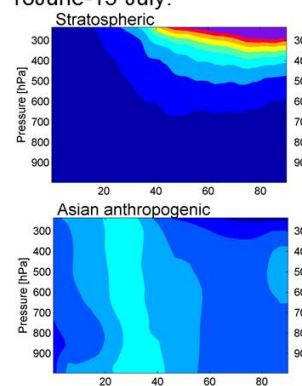
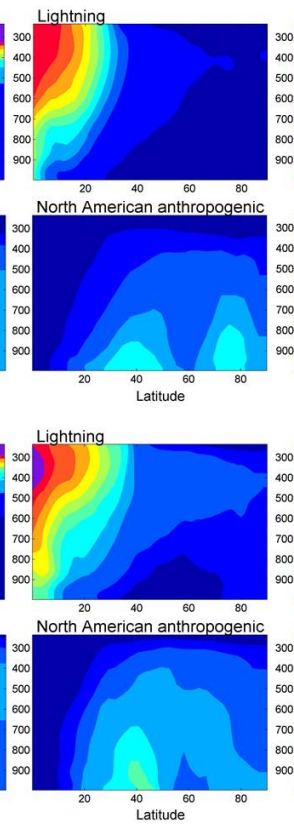
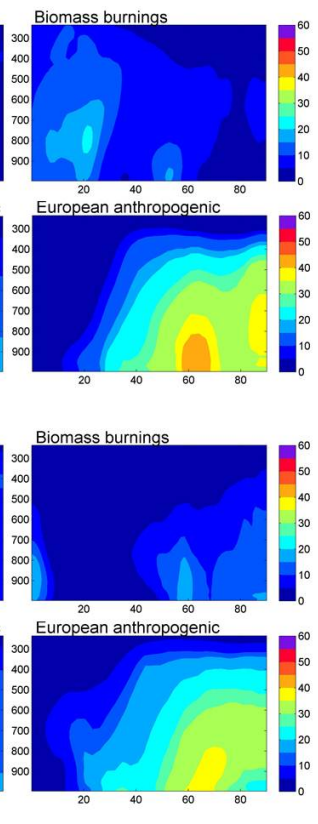

(b) $\underline{\mathrm{HNO}}_{3}$ contributions 1-19 April:
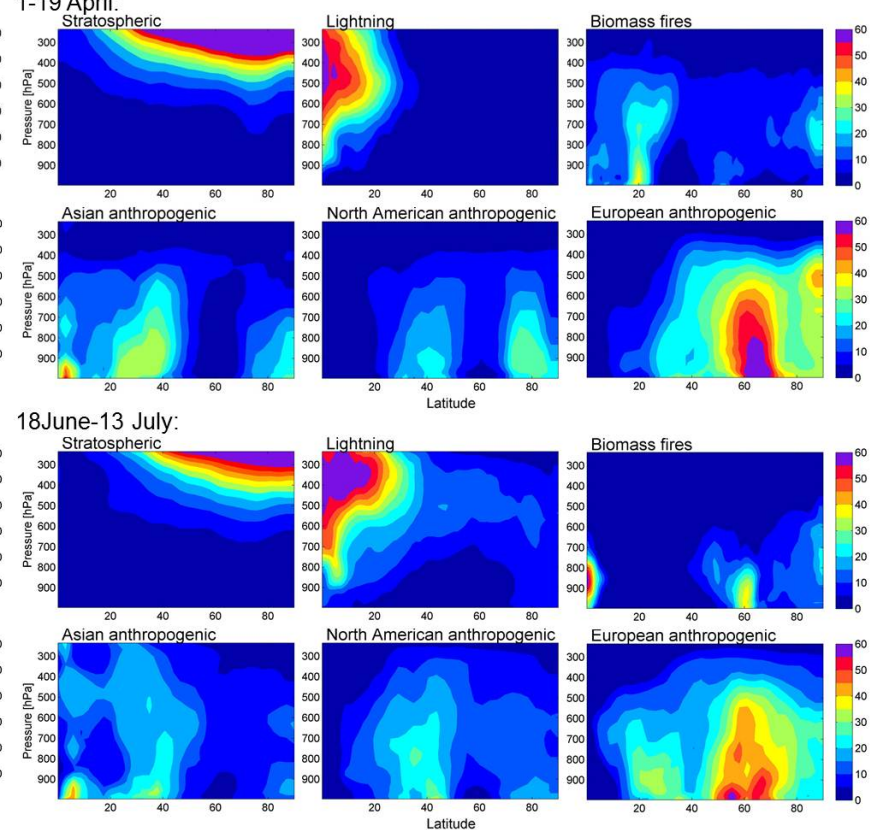

Fig. 10. Vertical and latitudinal distributions of the relative contributions (\%) to $\mathrm{O}_{3}$ (a) and $\mathrm{HNO}_{3}$ (b) concentrations during the spring (from 1 to 19 April) and summer (from 18 June to 13 July) ARCTAS campaigns, as simulated by MOZART-4.

As a result, the anthropogenic emissions contribute only slightly to the Arctic background concentrations of $\mathrm{HNO}_{3}$ $\left(5 \times 10^{14}\right.$ molecules $\left.\mathrm{cm}^{-2}\right)$. Even though they were particularly intense during the spring campaigns, the Southeast Asian fires show only a small influence on the Arctic due to the low latitude of the emissions. During the summer, Russian fire emissions greatly contribute to the tropospheric columns over Eastern Siberia $\left(3 \times 10^{17}\right.$ molecules $\mathrm{cm}^{-2}$ for $\mathrm{O}_{3}$ and $1.5 \times 10^{15}$ molecules $\mathrm{cm}^{-2}$ for $\mathrm{HNO}_{3}$ ) with some contributions over the American sector of the Arctic. Emissions from Californian fires are also observed. Finally, lightning which principally occurs at the equatorial belt also has a non-negligible contribution to the tropospheric columns of $\mathrm{O}_{3}\left(1 \times 10^{17}\right.$ molecules $\left.\mathrm{cm}^{-2}\right)$ and $\mathrm{HNO}_{3}\left(1 \times 10^{15}\right.$ molecules $\left.\mathrm{cm}^{-2}\right)$ in the Arctic principally during the summer.

Figure 10 presents the vertical and latitudinal distributions of the most important contributors to $\mathrm{O}_{3}$ (Fig. 10a) and $\mathrm{HNO}_{3}$ (Fig. 10b) for the spring and the summer periods, as simulated by MOZART-4. Consistent with studies of CO during ARCTAS (Fisher et al., 2010; Tilmes et al., 2011), anthropogenic pollution dominates concentrations over the Northern Hemisphere between the surface and $400 \mathrm{hPa}$, through lifting to the middle troposphere and transport towards higher latitudes. The European contribution particularly dominates throughout the Arctic, reaching up to $45 \%$ and $60 \%$ of the total abundance of $\mathrm{O}_{3}$ and $\mathrm{HNO}_{3}$, respectively. The Asian emissions are dominant below $40^{\circ} \mathrm{N}$ with a contribution of $35 \%$ for $\mathrm{O}_{3}$ and $\mathrm{HNO}_{3}$. They reach up to $20 \%$ of the Arctic background via uplift and transport associated with warm conveyor belts (WCBs) over China (Stohl, 2006). The much smaller North American emissions, which also involve uplift in WCBs, make a limited contribution to the Arctic concentrations of $20 \%$ between the surface and $700 \mathrm{hPa}$. The influence of the biomass burning emissions on the Arctic composition, with a contribution of around $15 \%$ on average for $\mathrm{O}_{3}$ and $\mathrm{HNO}_{3}$, results principally from the Siberian fires (maxima at $55-60^{\circ} \mathrm{N}$ ) occurring during spring and summer. The large fires in the Southeast Asian region in April (maxima at $20-30^{\circ} \mathrm{N}$ ) have a minimal impact on the Arctic abundances. Their contribution is smaller than the Asian anthropogenic contribution, even in the upper troposphere where it results from transport with WCBs (Bey et al., 2001). Subsiding stratospheric air masses dominate concentrations at pressure less than $400 \mathrm{hPa}$ into the Arctic, where they exceed $60 \%$ of $\mathrm{O}_{3}$ or $\mathrm{HNO}_{3}$ Arctic abundance. During April, transport from the stratosphere shows a contribution of around $10 \%$ down to the boundary layer. Contributions from lightning to the Arctic composition during April are relatively small, even at high altitude. During summer, they reach up to $20 \%$ of the $\mathrm{O}_{3}$ or $\mathrm{HNO}_{3}$ Arctic background concentrations at 400-500 hPa with some descent $(10 \%)$ down to the surface. It is also worth noting that, as previously discussed, the principal differences between the distributions of $\mathrm{O}_{3}$ and $\mathrm{HNO}_{3}$ lie in a deeper horizontal and vertical gradients for $\mathrm{HNO}_{3}$ concentrations.

Moreover, it is interesting to indicate that the partitioning based on the aircraft track flights (Fig. 8) is generally 
Table 2. Contribution, expressed in percentage (\%) of the total, of the principal sources of $\mathrm{O}_{3}$ and $\mathrm{HNO}_{3}$ in altitude bands of ground-700 $\mathrm{hPa}$, $700-450 \mathrm{hPa}$ and $450-300 \mathrm{hPa}$, based on the aircraft sampling $\left(>60^{\circ} \mathrm{N}\right)$ and for the entire Arctic $\left(>60^{\circ} \mathrm{N}\right)$ for the spring and the summer phases of the ARCTAS campaigns, as simulated by MOZART-4.

\begin{tabular}{|c|c|c|c|c|c|c|c|c|}
\hline \multirow[b]{2}{*}{ Contributions (\%) } & \multicolumn{4}{|c|}{ Spring period } & \multicolumn{4}{|c|}{ Summer period } \\
\hline & \multicolumn{2}{|c|}{$\mathrm{O}_{3}$} & \multicolumn{2}{|c|}{$\mathrm{HNO}_{3}$} & \multicolumn{2}{|c|}{$\mathrm{O}_{3}$} & \multicolumn{2}{|c|}{$\mathrm{HNO}_{3}$} \\
\hline \multicolumn{9}{|l|}{ Anthropogenic } \\
\hline North America $1000-700 \mathrm{hPa}$ & 19 & 24 & 21 & 35 & 16 & 30 & 14 & 29 \\
\hline $700-450 \mathrm{hPa}$ & 14 & 13 & 4 & 16 & 15 & 18 & 12 & 11 \\
\hline $450-300 \mathrm{hPa}$ & 8 & 8 & 7 & 8 & 12 & 10 & 8 & 4.5 \\
\hline \multirow{3}{*}{ Europe } & 37 & 29 & 3 & 21 & 34 & 27 & 39 & 29 \\
\hline & 31 & 23 & 5 & 21 & 30 & 16 & 33 & 13 \\
\hline & 15 & 13 & 14 & 8 & 19 & 12 & 15 & 4.5 \\
\hline \multirow{3}{*}{ Asia } & 18 & 19 & 0 & 22 & 13 & 13 & 10 & 10 \\
\hline & 15 & 21 & 0 & 23 & 15 & 14 & 10 & 9 \\
\hline & 10 & 14 & 6 & 11 & 12 & 14 & 6 & 4 \\
\hline \multirow[t]{3}{*}{ Biomass burning Total } & 4.5 & 5.5 & 9 & 14 & 14 & 8 & 17 & 14 \\
\hline & 5 & 6 & 9 & 14 & 9 & 11 & 12 & 23 \\
\hline & 3 & 5 & 4.5 & 9 & 5 & 6 & 4 & 3 \\
\hline \multirow[t]{3}{*}{ Stratospheric } & 11 & 9.5 & 2.5 & 4 & 3 & 4 & 2 & 2 \\
\hline & 19 & 19 & 13 & 17 & 10 & 16 & 12 & 21 \\
\hline & 48 & 43 & 49 & 49 & 28 & 37 & 41 & 56 \\
\hline \multirow[t]{3}{*}{ Lightning } & 3 & 3 & 3 & 1 & 8 & 6 & 7 & 5 \\
\hline & 0.1 & 5 & 0.1 & 2 & 0.3 & 15 & 0.3 & 13 \\
\hline & 0.006 & 6 & 0 & 4 & 0.007 & 13 & 0.002 & 10 \\
\hline
\end{tabular}

Left: for the entire Arctic $\left(>60^{\circ} \mathrm{N}\right)$

Right: based on aircraft sampling $\left(>60^{\circ} \mathrm{N}\right)$

different from that for entire Arctic (Fig. 10), except for middle/upper tropospheric $\mathrm{O}_{3}$, which is longer-lived and better mixed than $\mathrm{HNO}_{3}$. Table 2 summarizes the contribution of the principal sources based on the aircraft sampling and for the entire Arctic, for the spring and the summer phase of the ARCTAS campaigns. The aircraft sampling patterns are observed to influence the partitioning analysis, with an overrepresentation of the North American anthropogenic contribution $\left(\sim 10 \%\right.$ for $\mathrm{O}_{3}$ and $\sim 15 \%$ for $\mathrm{HNO}_{3}$ on average) and an underrepresentation of the European anthropogenic contribution $\left(\sim 10 \%\right.$ for $\mathrm{O}_{3}$ and $\sim 17 \%$ for $\mathrm{HNO}_{3}$ on average) in the lower/middle troposphere, in comparison with partitioning from the entire Arctic. The overestimation of the biomass burning contribution to lower/middle tropospheric $\mathrm{HNO}_{3}$, based on aircraft sampling patterns, reflects the influence from intense Asian fires in addition to the impact of Canadian fires during the summer. The lightning contribution over all the troposphere and the stratospheric contribution in the middle/upper troposphere for the summer period are also influenced by the aircraft sampling patterns.

\section{Tropospheric $\mathrm{O}_{3}$ observed by FTIR and IASI during ARCTAS}

In this section, we test the ability of the FTIR and IASI instruments to observe the long-range transport of pollution into the Arctic by investigating the daily variability of $\mathrm{O}_{3}$ measurements from IASI and from FTIR at Eureka $\left(80^{\circ} \mathrm{N}\right.$, $\left.86^{\circ} \mathrm{W}\right)$ and at Thule $\left(77^{\circ} \mathrm{N}, 69^{\circ} \mathrm{W}\right)$ in comparison with the MOZART-4 results previously evaluated in Sect. 3. Based on an IASI sensitivity analysis, we consider, in this section, tropospheric columns between ground and $300 \mathrm{hPa}$ both to limit as much as possible the stratospheric and the tropopause height variation influence and to contain the altitude range of maximum sensitivity in the troposphere (see Sect. 2.2). We also make a further use of the tagged tracers to assist in the interpretation of the $\mathrm{O}_{3}$ variability observed by these instruments.

\subsection{FTIR observations of Arctic pollution}

Figure 11 (top) shows the comparison of model results with observations of daily mean $\mathrm{O}_{3}$ columns from ground to $300 \mathrm{hPa}$, from FTIR observations at Eureka and at Thule during spring and summer 2008. For the purpose of the 

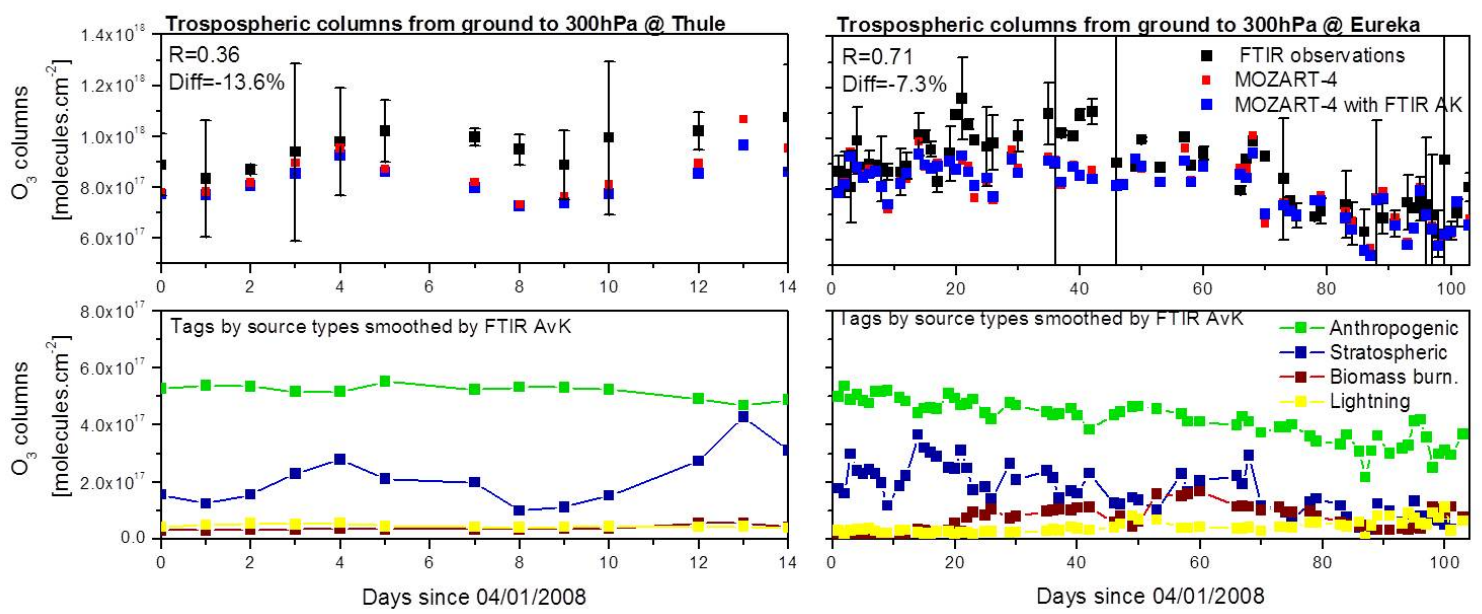

Fig. 11. Top: daily mean $\mathrm{O}_{3}$ columns from ground to $300 \mathrm{hPa}$ at Thule (left) for 1 to 15 April 2008 and at Eureka (right) for 1 April to 13 July 2008. The ground-based FTIR measurements (black) are compared to raw model values (red) and smoothed (blue) with the FTIR averaging kernels. Vertical bars represent the daily variability associated with the tropospheric columns ( $3 \sigma$, where $\sigma$ is the daily standard deviation). The correlation coefficient and median of the differences between the observations and the model (calculated as [(model-obs.)/obs.].100\%) are also indicated. Bottom: contributions of principal sources to $\mathrm{O}_{3}$ tropospheric columns over Thule (left) for 1 to 15 April 2008 and Eureka (right) for 1 April to 13 July 2008, smoothed with the FTIR averaging kernels.

comparison, MOZART-4 results have been smoothed by the FTIR averaging kernels (see Sect. 2.2, Fig. 2). Comparison of measurements with model results shows good agreement within $1 \times 10^{17}$ molecules $\mathrm{cm}^{-2}$, with a negative bias within $-15 \%$ on average. This can be explained by the underestimation of model results of around $5-15 \%$ as discussed in Sect. 3, by the retrieval total errors (Sect. 2.2) and by the daily variation associated with the FTIR observations (vertical bars in Fig. 11).

Similarly to the partitioning analysis along the flight tracks (Sect. 4.1), MOZART-4 simulations have been used to simulate the FTIR tropospheric $\mathrm{O}_{3}$ contributions from the principal sources: stratospheric, anthropogenic, biomass burning and lightning (Fig. 11, bottom). Following the formalism of Rodgers (2000) (Eq. (1), Sect. 2.2), it can be shown that:

$\boldsymbol{x}_{\text {Model Smoothed }}=\boldsymbol{x}_{\mathrm{a}}+\mathbf{A}\left[\left(\Sigma \boldsymbol{x}_{\text {Tracer }}\right)-\boldsymbol{x}_{\mathrm{a}}\right]$

where $\boldsymbol{x}_{\text {Tracer }}$ represents the profile from each tagged contribution. This expression can be separated into two components: one representing the contributions from each tracer smoothed by the averaging kernels, calculated as $\mathbf{A}\left(\boldsymbol{x}_{\text {Tracer }}\right)$, and the second, the a priori contribution, representing the contribution from the a priori to the retrieved tropospheric columns, due to the limited vertical sensitivity of the instrument. It is calculated as $\boldsymbol{x}_{\mathrm{a}}-\mathbf{A}\left(\boldsymbol{x}_{\mathrm{a}}\right)$.

The observations at Thule and Eureka are dominated by the anthropogenic contribution, followed by the stratospheric influence (Fig. 11, bottom). At Thule, the anthropogenic pollution represents, on average, $54 \%$ of total concentration (23\% from North America, $18 \%$ from Europe and $12 \%$ from Asia), the stratospheric fluxes count for $21 \%$ and light- ning for $5 \%$. Some contribution from biomass burning is also likely affecting the FTIR measurements to a weak extent (less than $4 \%$ ). The small fraction from the a priori information (only $1.2 \%$ ) reflects a high vertical sensitivity throughout the troposphere. The differences between the total simulation and the sum of the tagged contributions (around 15\% on average) can be attributed to the contribution from soils and aircraft emissions. The day-to-day variability observed at Thule can mainly be attributed to the day-to-day variability associated with the stratospheric flux of ozone, which shows an amplitude of $3 \times 10^{17}$ molecules $\mathrm{cm}^{-2}$.

At Eureka, the contributions are identified as follows: $52 \%$ from the anthropogenic sources (14\% from North America, $23 \%$ from Europe and $14 \%$ from Asia), $20 \%$ from the stratospheric flux, smaller influence from biomass fires $(9 \%)$ and from lightning $(6 \%)$ and a negligible a priori contribution $(1 \%)$. The stratospheric and the anthropogenic sources have the most variability, with amplitudes of $3 \times 10^{17}$ molecules $\mathrm{cm}^{-2}$ and $2 \times 10^{17}$ molecules $\mathrm{cm}^{-2}$ respectively. The anthropogenic source amplitude over the campaign periods shows up as a decrease in the summer while the stratospheric source is strongly variable on a daily basis, though being also much less in summer as compared to spring. As discussed in Sect. 4.2, the contributions from lightning to the Arctic composition are small during April, but they are as large as $18 \%$ during the summer. The most elevated concentrations from fires over May and June with contributions reaching up to $20 \%$ principally result from the Siberian emissions. 

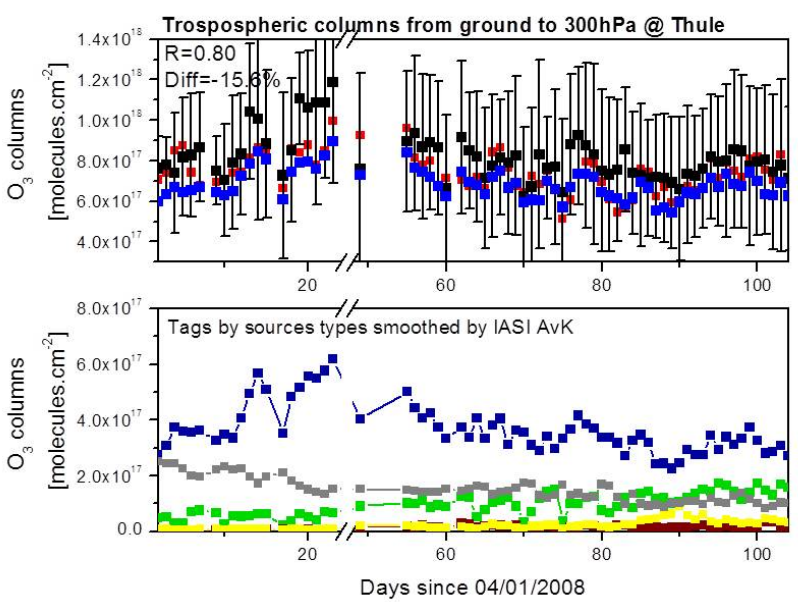
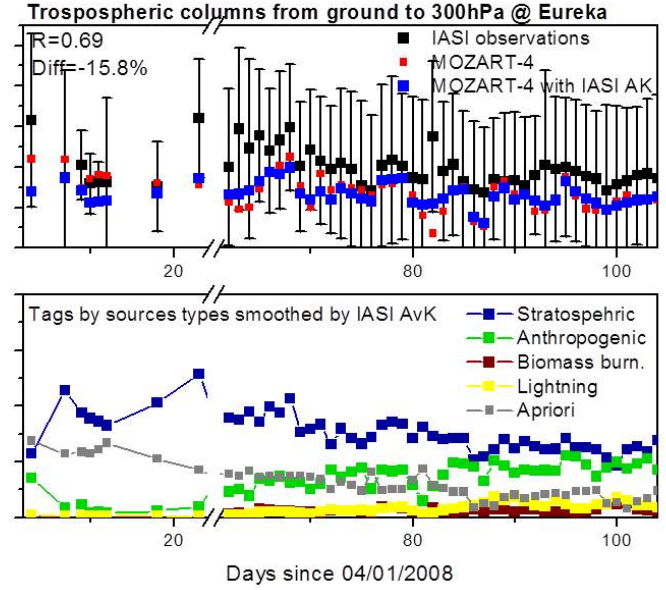

Fig. 12. Same as Fig. 11 but for comparison with IASI satellite measurements within the $1.4^{\circ} \times 1.4^{\circ}$ MOZART- 4 grid around Thule (left) or Eureka (right).

\subsection{IASI observations of Arctic pollution}

Figure 12 is similar to Fig. 11, but for the IASI observations extracted within the MOZART grid box around Thule or Eureka. Here, MOZART-4 results have been smoothed by the IASI averaging kernels (see Sect. 2.2, Fig. 2). Comparison of the measurements with model results shows an agreement within $1-2 \times 10^{17}$ molecules $\mathrm{cm}^{-2}$ on average, which corresponds to a negative average bias of around $-15 \%$. It probably reflects, on one hand, the tendency of IASI retrievals to overestimate the tropospheric ozone columns by $\sim 10 \%$ in the Northern latitudes (Boynard et al., 2009), and, on the other hand, the underestimation of the concentrations from MOZART-4 in these latitudes (see Sect. 3). It also can be largely explained by the IASI daily variations ( $3 \sigma$ values of $\sim 6 \times 10^{17}$ molecules $\mathrm{cm}^{-2}$ on average).

Contrary to the FTIR observations, the observations from IASI at Thule and Eureka are dominated by the stratospheric contribution. This results from a higher sensitivity of IASI in the higher layers where the stratospheric influence represents the largest contributions (Figs. 7 and 10). This also makes the underrepresentation of the stratospheric influence in the model (reaching $25 \%$, as previously discussed when comparing aircraft data and model results in Sect. 3) largely responsible for the differences between the IASI observations and the model results. The IASI measurements are also more affected by the a priori information than the ground-based FTIR measurements, because of a lower vertical sensitivity of IASI in the lowest layers. As a consequence, IASI detects smaller contributions from anthropogenic pollution and fires than the FTIR instruments.

At Thule, the stratospheric and the anthropogenic contributions represent, on average, $53 \%$ and $14 \%$ of the total concentration (with $5.5 \%$ from North America, $4.5 \%$ from Europe and $4.0 \%$ from Asia) respectively. The a priori infor- mation contributes importantly with $22 \%$ over the entire troposphere. The contribution from fires, mainly from Siberia, and from lightning is significantly weaker (less than $3.5 \%$ each on average). Contributions of $6 \%$ from soils and aircraft emissions were calculated. The day-to-day variability can mainly be attributed to the variability of the ozone stratospheric contribution, which shows large amplitudes up to $3 \times 10^{17}$ molecules $\mathrm{cm}^{-2}$, as indicated by the MOZART- 4 simulations.

At Eureka, the stratospheric influence is again the most important ( $46.1 \%$ on average) decreasing over the summer. The relative contribution from the anthropogenic sources accounts for $17 \%$ (5.5\% from North America, $6.5 \%$ from Europe and $5.0 \%$ from Asia). The a priori contribution represents a fraction of $19 \%$. Influences from fires and from lightning contribute to the Eureka background concentration with a fraction smaller than $4.5 \%$ each. Both the stratospheric and the anthropogenic sources have the maximum variability, with amplitudes of $3 \times 10^{17}$ molecules $\mathrm{cm}^{-2}$ and $2 \times 10^{17}$ molecules $\mathrm{cm}^{-2}$ respectively. It is also worth pointing out that IASI retrievals at Thule and at Eureka are characterized by a sharp decrease of the a priori contribution between April and July observations, with contributions ranging from $3 \times 10^{17}$ molecules $\mathrm{cm}^{-2}$ to $5 \times 10^{16}$ molecules $\mathrm{cm}^{-2}$. The larger contribution during the spring reflects a lack of sensitivity probably due to both smaller thermal signal above ice-covered surfaces and smaller thermal contrast in the cold boundary layers.

In order to further test the ability of IASI to observe the transport and the variability over the scale of the Arctic, Fig. 13 shows the mean $\mathrm{O}_{3}$ columns from ground to $300 \mathrm{hPa}$ during the ARCTAS spring and summer periods as observed by IASI and compared to MOZART-4 model values. The horizontal distributions of the Northern latitude concentrations show similar patterns between the observations and the 

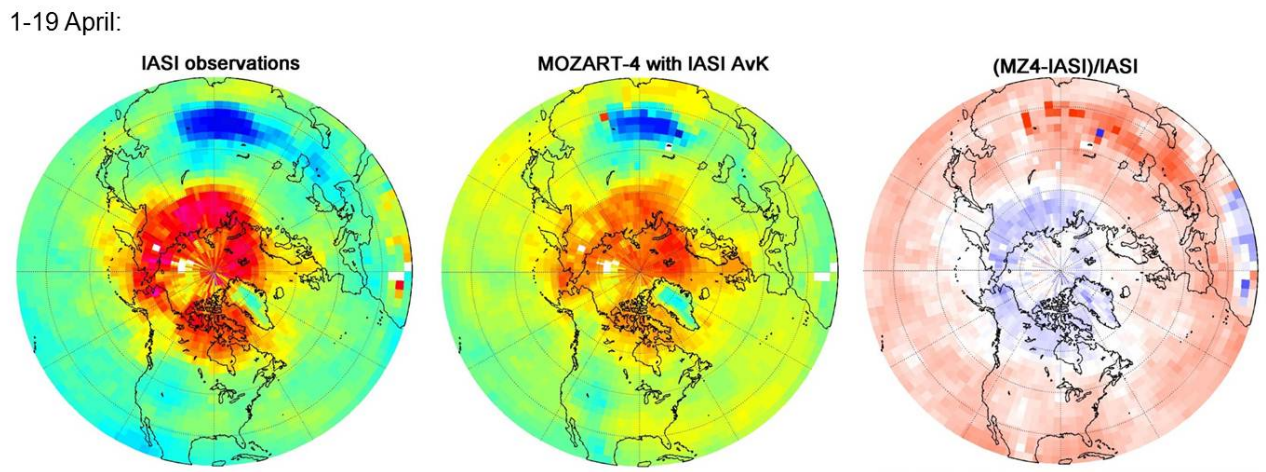

18June-13 July:
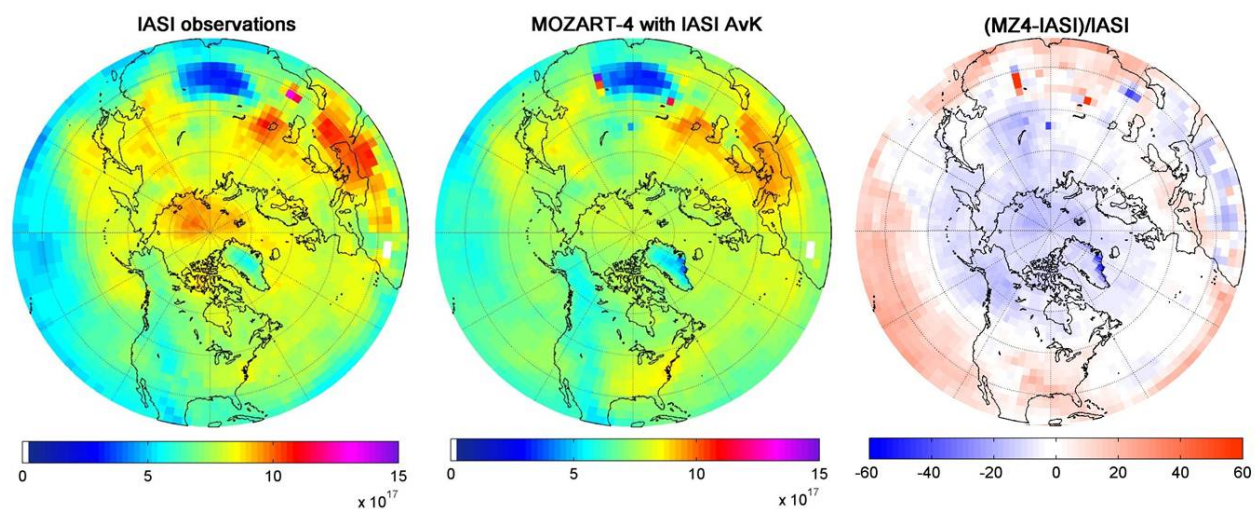

Fig. 13. Mean $\mathrm{O}_{3}$ columns $\left(\times 10^{17}\right.$ molecules $\left.\mathrm{cm}^{-2}\right)$ from ground to $300 \mathrm{hPa}$ during the spring (from 1 to 19 April) and summer (from 18 June to 13 July) campaign periods, observed by the IASI satellite instrument and simulated by MOZART-4, smoothed according to the averaging kernels of the IASI observations. The percent differences between the observations and the model results (calculated as [(modelobs.)/obs.] $100 \%$ ) are shown on the right panel.

simulations. During the spring, both IASI and MOZART-4 show highest concentrations over the Arctic, while during the summer, the highest values are observed above south-west Asia. Observations and model datasets are reasonably well correlated ( $R=0.79$ during the spring and $R=0.88$ during the summer campaign periods) and the mean relative differences $(4.1 \pm 39.4 \%$ and $-4.4 \pm 29.9 \%$, respectively for the two periods) indicates the absence of a systematic bias between the model and the observations. The high differences (averaged negative bias of around $20 \%$ ) observed over the Arctic can be explained by the underestimation of the stratospheric contribution in the model (as previously discussed for observations at Eureka and at Thule), while the averaged positive bias (around 20\%) measured at low latitudes could be mostly attributed to the tendency of MOZART- 4 to overestimate the $\mathrm{O}_{3}$ concentrations in the Northern Tropics (Emmons et al., 2010a) and to larger total retrieval errors on the IASI tropospheric columns, principally found at the intertropical latitudes $(\sim 15 \%$ on average, Sect. 2.2$)$. These larger total errors are possibly due to the stronger impact of the water vapor lines on $\mathrm{O}_{3}$ retrievals at these latitudes (Hurtmans et al., 2011). Dilution on the model spatial scale $(\sim 140 \mathrm{~km})$ compared to IASI spatial scale $(\sim 12 \mathrm{~km}$ at nadir) could also explain a part of the differences. These differences lead to a stronger latitudinal gradient from IASI observations in comparison to that from the model.

Figure 14 shows $\mathrm{O}_{3}$ columns from ground to $300 \mathrm{hPa}$ as observed by IASI and modeled by MOZART-4 during two specific episodes of pollution transport across the Arctic: 14-16 April during the spring campaign and 2-5 July during the summer campaign. Principal contributions (stratospheric, anthropogenic, fires and lightning) as simulated by the model and smoothed using the IASI averaging kernels are also shown for the purpose of our analysis. Both IASI and MOZART-4 show elevated columns over Northern latitudes. Based on modeled source contributions, this enhancement reflects principally a strong stratospheric influence during the spring, while it mainly results from a mix of anthropogenic pollution from Europe, Asia and North America during the summer. Similar to the analysis presented in Sect. 4.2., the highest values for anthropogenic pollution (up to $7 \times 10^{17}$ molecules $\mathrm{cm}^{-2}$ ) are observed over the European sector of the Arctic during the two periods (a contribution of $\sim 50 \%$ to the tropospheric column), followed by maxima of $5 \times 10^{17}$ molecules $\mathrm{cm}^{-2}$ over the Asian and the American sectors (see Sect. 4.2). Large anthropogenic plumes from 

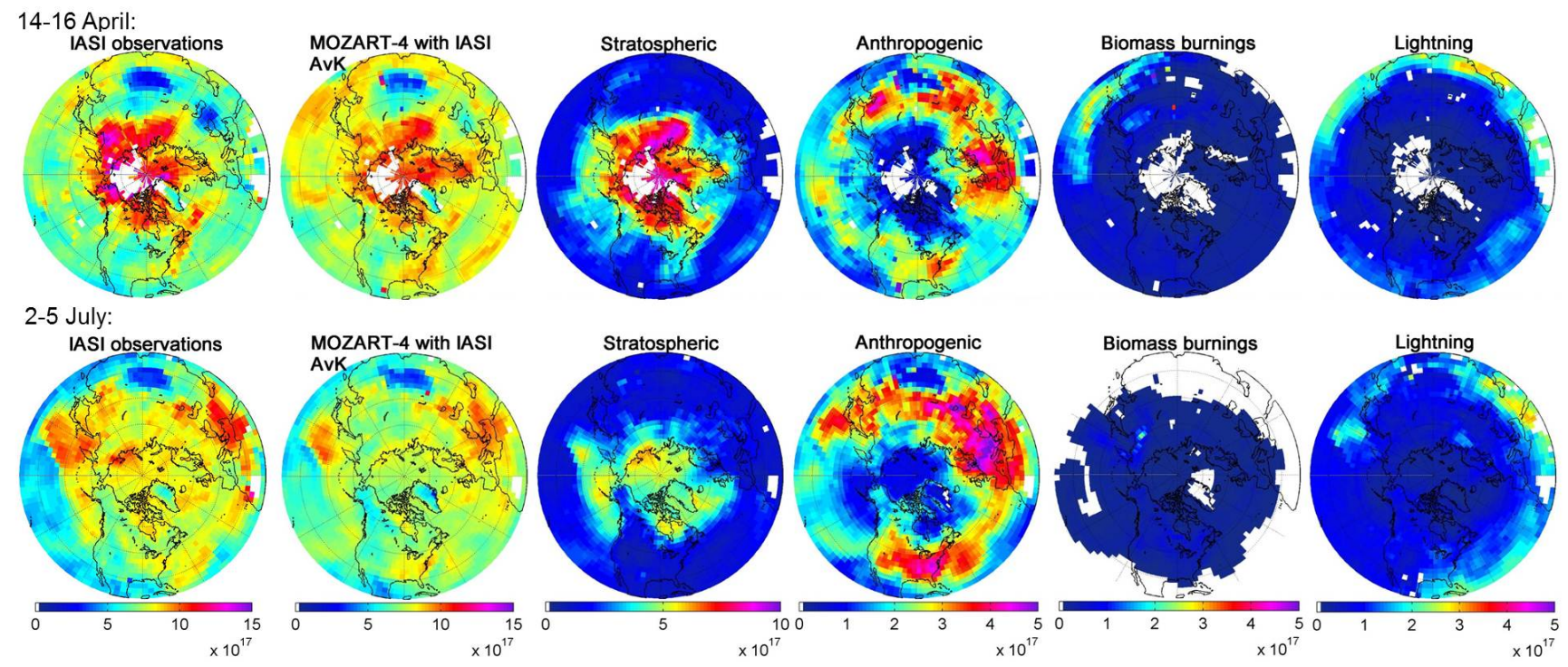

Fig. 14. Mean $\mathrm{O}_{3}$ columns (molecules $\mathrm{cm}^{-2}$ ) from ground-300 hPa, over 14-16 April and 2-5 July periods observed by the IASI satellite instrument and simulated by MOZART- 4 smoothed according to the averaging kernels of IASI observations. Contributions of principal sources to $\mathrm{O}_{3}$ tropospheric columns as modeled in MOZART-4 and smoothed with the IASI averaging kernels are also shown.

Europe to Asia through a westerly trans-Siberian transport pathway, from eastern Asia across the Pacific and from eastern USA across the Atlantic are clearly shown in the distributions. This example illustrates the ability of IASI to observe anthropogenic outflow transported over a long distance and reaching the Arctic border. However, evidence of enhanced ozone from a mix of anthropogenic pollution is not clearly detected from the anthropogenic contribution smoothed using the IASI averaging kernels. This results from a sharp decrease of the IASI vertical sensitivity in the middle/lower troposphere above these cold ice-covered surfaces even during the summer time. This lack of vertical sensitivity over the Arctic leads to a collar region of enhanced anthropogenic ozone circling the colder Arctic, in contrast to the non-smoothed MOZART-4 anthropogenic tag (see Sect. 4.2, Fig. 9). This collar region is characterized by DOFS larger than 3.2 while colder Arctic surfaces show lower DOFS. This threshold DOFS value of $\sim 3.2$ indicates the minimum sensitivity required for the detection of anthropogenic ozone into the Arctic. Principally during April, evidence for biomass burning emissions from eastern Asia (reaching concentration of $3 \times 10^{17}$ molecules $\mathrm{cm}^{-2}, \sim 30 \%$ of tropospheric columns) with some transport to higher latitudes are also detected in the IASI measurements. Finally, some contributions from lightning to tropospheric $\mathrm{O}_{3}$ as observed by IASI are also detected in higher latitudes principally during the summer with values of $\sim 1 \times 10^{17}$ molecules $\mathrm{cm}^{-2}$ (reaching $15 \%$ of the tropospheric columns).

\section{Conclusions}

$\mathrm{O}_{3}$ and $\mathrm{HNO}_{3}$ observations from the NASA ARCTAS and NOAA ARCPAC aircraft campaigns provide information of the sources of pollution into the Arctic during spring and summer 2008.

The MOZART- 4 model generally reproduces the variability of observations in space and time for both $\mathrm{O}_{3}$ and $\mathrm{HNO}_{3}$, especially during ARCTAS. During ARCPAC, the long-distance displacement and smearing of plumes from sources into the Alaskan Arctic seems to introduce larger model error. The model underestimates both $\mathrm{O}_{3}$ and $\mathrm{HNO}_{3}$ concentrations by $5-15 \%$ and $3-35 \%$, respectively. For the ARCTAS measurements, the underestimation of $\mathrm{O}_{3}$ and $\mathrm{HNO}_{3}$ concentrations is attributed to an underrepresentation of both anthropogenic sources and stratospheric influence. During ARCPAC, the underestimation is tied to an underrepresentation of anthropogenic sources and Russian fires emissions. The $\mathrm{O}_{3} / \mathrm{HNO}_{3}$ ratio characterizing different air mass types (fresh plumes, free troposphere and stratospherecontaminated air masses) are well reproduced in the model. The largest differences between observations and model are observed in the freshly polluted plumes of the ARCTASCARB and the ARCTAS-B campaigns, pointing to the probable impact of the coarse model resolution and the associated diffusion on $\mathrm{O}_{3}$ production in polluted regions. In summary, the underestimation of concentrations in the model could result from a mix of uncertainties in emission inventories, underestimation of the stratospheric influence, transport errors in the model introduced by too much diffusion due to the coarse resolution of the model and interpolation 
of the MOZART-4 results (from 6-h averages) to the flight path (1-min averages). In the spring Arctic boundary layer, the misrepresentation of extremely low values of $\mathrm{O}_{3}$ is attributed to the missing treatment of the halogen chemistry in MOZART-4.

Over the scale of the Arctic, we find that anthropogenic pollution, especially from Europe, dominates concentrations over the Arctic below $400 \mathrm{hPa}$ (up to $45 \%$ and $60 \%$ of total abundance of $\mathrm{O}_{3}$ and $\mathrm{HNO}_{3}$ respectively). This principally reflects lifting to the middle troposphere with northward and westerly trans-Siberian transport pathways. The stratospheric influence dominates concentrations above $400 \mathrm{hPa}$ in the Arctic $(\sim 60 \%)$. The Asian emissions and the much smaller North American emissions contributes weakly up to $20 \%$ of the Arctic background between the surface and $500 \mathrm{hPa}$. Important contributions from Siberian fires reaching the American sector of the Arctic and from Californian fires are also clearly observed. We also found that the principal differences between the distributions of $\mathrm{O}_{3}$ and $\mathrm{HNO}_{3}$ lie in a deeper horizontal and vertical gradient for $\mathrm{HNO}_{3}$ concentrations, because of its shorter lifetime and consequently weaker mixing of $\mathrm{HNO}_{3}$ than of $\mathrm{O}_{3}$ throughout the troposphere.

Finally, through comparisons with MOZART-4 total and tagged tracers results, we demonstrate that ground-based FTIR and IASI satellite instruments capture the temporal variations of Northern Hemisphere pollution during the ARCTAS campaigns, with events in the free troposphere, but the satellite observations are less sensitive in the lowermost layers. We show that the $\mathrm{O}_{3}$ observations from FTIR instruments at Thule and Eureka are dominated by stratospheric and anthropogenic influences $(20 \%$ and $55 \%$, respectively) while the observations from the IASI satellite principally reflect the stratospheric contribution $(\sim 50 \%)$ due to the weaker IASI sensitivity in the lowest layers. As a result, we also find that the IASI measurements are characterized by a stronger contribution from the a priori information ( $\sim 20 \%$ for IASI vs. $\sim 1 \%$ for FTIR) and a smaller contribution from anthropogenic pollution and fires $(\sim 15 \%$ for IASI vs. $\sim 55 \%$ for FTIR and $<5 \%$ for IASI vs. $10 \%$ FTIR, respectively) than FTIR measurements.

For the extratropical Northern Hemisphere, IASI measurements capture well the mean spatial structure of tropospheric ozone during the spring and the summer 2008, with a good correlation and a good mean relative difference between observations and model. The relative difference of $20 \%$ between IASI observations and model results over all the Arctic further illustrates the underestimation of the stratospheric fluxes in the model. We also demonstrated, for the first time, the capability of the IASI satellite to detect $\mathrm{O}_{3}$ polluted plumes from fires or anthropogenic emissions during spring and summer 2008, over long distances to the Arctic, but not over the colder surface of the Arctic because of a lack of sensitivity above snow and ice.
Transport of $\mathrm{O}_{3}$ into high latitudes can strongly impact the radiative forcing of climate and the oxidizing capacity of the troposphere. We demonstrate in this study the capability of combining global model and remote sensing instruments for better observing and quantifying the long-range transport of pollution into the Arctic. It opens perspectives for further studies in exploring the trend in tropospheric ozone pollution and its impact on chemistry and climate. Furthermore, work is in progress to investigate the relevant information for tropospheric $\mathrm{HNO}_{3}$ from the IASI measurements which would be useful in improving our understanding of the $\mathrm{HO}_{\mathrm{x}}-\mathrm{NO}_{\mathrm{y}}-$ $\mathrm{O}_{3}$ system from a more global perspective.

Acknowledgements. The National Center for Atmospheric Research is supported by the National Science Foundation. The NCAR FTS observation program at Thule, GR is supported under contract by the National Aeronautics and Space Administration (NASA). This work is also supported by the NSF Office of Polar Programs (OPP). We wish to thank the Danish Meteorological Institute for support at the Thule site. The PEARL Bruker 125HR measurements at Eureka were made by the Canadian Network for the Detection of Atmospheric Change (CANDAC), led by James R. Drummond, and in part by the Canadian Arctic ACE Validation Campaigns,led by Kaley A. Walker. They were supported by the Atlantic Innovation Fund/Nova Scotia Research Innovation Trust, Canada Foundation for Innovation, Canadian Foundation for Climate and Atmospheric Sciences, Canadian Space Agency, Environment Canada, Government of Canada International Polar Year funding, Natural Sciences and Engineering Research Council, Northern Scientific Training Program, Ontario Innovation Trust, Polar Continental Shelf Program, and Ontario Research Fund. The authors wish to thank PEARL site manager Pierre F. Fogal, the CANDAC operators, and the staff at Environment Canada's Eureka weather station for logistical and on-site support. IASI has been developed and built under the responsibility of the Centre National d'Etudes Spatiales (CNES, France). It is flown onboard the Metop satellites as part of the EUMETSAT Polar System. The IASI L1 data are received through the EUMETCast near real time data distribution service. P. F. Coheur is Research Associate (Chercheur Qualifié) with F.R.S.-FNRS. The research in Belgium was funded by the F.R.S.-FNRS (M.I.S. nF.4511.08), the Belgian State Federal Office for Scientific, Technical and Cultural Affairs and the European Space Agency (ESA-Prodex arrangements). Financial support by the 'Actions de Recherche Concertées' (Communauté Française de Belgique) is also acknowledged. The research in France is supported by CNES. This research has been supported by NASA's Tropospheric Chemistry Program (ARCTAS) under grant NNX08AD22G, NNX08AD29G, and NNX07AL57G.

Edited by: J. W. Bottenheim 


\section{References}

Alvarado, M. J., Logan, J. A., Mao, J., Apel, E., Riemer, D., Blake, D., Cohen, R. C., Min, K.-E., Perring, A. E., Browne, E. C., Wooldridge, P. J., Diskin, G. S., Sachse, G. W., Fuelberg, H., Sessions, W. R., Harrigan, D. L., Huey, G., Liao, J., Case-Hanks, A., Jimenez, J. L., Cubison, M. J., Vay, S. A., Weinheimer, A. J., Knapp, D. J., Montzka, D. D., Flocke, F. M., Pollack, I. B., Wennberg, P. O., Kurten, A., Crounse, J., Clair, J. M. St., Wisthaler, A., Mikoviny, T., Yantosca, R. M., Carouge, C. C., and Le Sager, P.: Nitrogen oxides and PAN in plumes from boreal fires during ARCTAS-B and their impact on ozone: an integrated analysis of aircraft and satellite observations, Atmos. Chem. Phys., 10, 9739-9760, doi:10.5194/acp-10-9739-2010, 2010.

Antón, M., Loyola, D., Clerbaux, C., López, M., Vilaplana, J. M.., Bañón, M., Hadji-Lazaro, J., Valks, P., Hao, N., Zimmer, W., Coheur, P. F., Hurtmans, D., and Alados-Arboledas, L.: Validation of the Metop-A total ozone data from GOME-2 and IASI using reference ground-based measurements at the Iberian Peninsula, Remote Sens. Environ., 115, 1380-1386, 2011.

Batchelor, R. L., Strong, K., Lindenmaier, R., Mittermeier, R. L., Fast, H., Drummond, J. R., and Fogal, P. F.: A new Bruker IFS 125HR FTIR spectrometer for the Polar Environment Atmospheric Research Laboratory at Eureka, Canada: measurements and comparison with the existing BomemDA8 spectrometer, J. Atmos. Ocean. Tech., 26, 13281340, doi:10.1175/2009JTECHA1215.1, 2009.

Bey, I., Jacob, D. J., Logan, J. A., and Yantosca, R. M.: Asian chemical out?ow to the Paci?c in spring: Origins, pathways, and budgets, J. Geophys. Res., 106, 23097-23113, 2001.

Bouwman, A. F., Boumans, L. J. M., and Batjes, N. $\mathrm{H}$.: Modeling global annual $\mathrm{N} 2 \mathrm{O}$ and $\mathrm{NO}$ emissions from fertilized fields, Global Biogeochem. Cy., 16, 1080, doi:10.1029/2001GB001812, 2002.

Boynard, A., Clerbaux, C., Coheur, P.-F., Hurtmans, D., Turquety, S., George, M., Hadji-Lazaro, J., Keim, C., and MeyerArnek, J.: Measurements of total and tropospheric ozone from IASI: comparison with correlative satellite, ground-based and ozonesonde observations, Atmos. Chem. Phys., 9, 6255-6271, doi:10.5194/acp-9-6255-2009, 2009.

Bregman, A., van Velthoven, P. F. J., Wienhold, F. G., Fischer, H., Zenker, T., Waibel, A., Frenzel, A., Arnold, F., Harris, G. W., Bolder, M. J. A., and Lelieveld, J.: Aircraft measurements of $\mathrm{O}_{3}$, $\mathrm{HNO}_{3}$, and $\mathrm{N}_{2} \mathrm{O}$ in the winter Arctic lower stratosphere during the Stratosphere-Troposphere Experiment by Aircraft Measurements (STREAM) 1, J. Geophys. Res., 100, 11245-11260, 1995.

Brock, C. A., Cozic, J., Bahreini, R., Froyd, K. D., Middlebrook, A. M., McComiskey, A., Brioude, J., Cooper, O. R., Stohl, A., Aikin, K. C., de Gouw, J. A., Fahey, D. W., Ferrare, R. A., Gao, R.-S., Gore, W., Holloway, J. S., Hübler, G., Jefferson, A., Lack, D. A., Lance, S., Moore, R. H., Murphy, D. M., Nenes, A., Novelli, P. C., Nowak, J. B., Ogren, J. A., Peischl, J., Pierce, R. B., Pilewskie, P., Quinn, P. K., Ryerson, T. B., Schmidt, K. S., Schwarz, J. P., Sodemann, H., Spackman, J. R., Stark, H., Thomson, D. S., Thornberry, T., Veres, P., Watts, L. A., Warneke, C., and Wollny, A. G.: Characteristics, sources, and transport of aerosols measured in spring 2008 during the aerosol, radiation, and cloud processes affecting Arctic Climate (ARCPAC) Project, Atmos. Chem. Phys., 11, 2423-2453, doi:10.5194/acp-11-2423-
2011, 2011.

Clerbaux, C., Boynard, A., Clarisse, L., George, M., Hadji-Lazaro, J., Herbin, H., Hurtmans, D., Pommier, M., Razavi, A., Turquety, S., Wespes, C., and Coheur, P.-F.: Monitoring of atmospheric composition using the thermal infrared IASI/MetOp sounder, Atmos. Chem. Phys., 9, 6041-6054, doi:10.5194/acp-9-6041-2009, 2009.

Coheur, P.-F., Clarisse, L., Turquety, S., Hurtmans, D., and Clerbaux, C.: IASI measurements of reactive trace species in biomass burning plumes, Atmos. Chem. Phys., 9, 5655-5667, doi:10.5194/acp-9-5655-2009, 2009.

Cooper, O. R., Moody, J. L., Parrish, D. D., Trainer, M., Holloway, J. S., Hubler, G., Fehsenfeld, F. C., and Stohl, A.: Trace gas composition of midlatitude cyclones over the western North Atlantic Ocean: A seasonal comparison of $\mathrm{O}_{3}$ and CO, J. Geophys. Res., 107, 4057, doi:10.1029/2001JD000902, 2002.

Cooper, M., Martin, R. V., Sauvage, B., Boone, C. D., Walker, K. A., Bernath, P. F., McLinden, C. A., Degenstein, D. A., Volz-Thomas, A., and Wespes, C.: Evaluation of ACE-FTS and OSIRIS satellite retrievals of ozone and nitric acid in the tropical upper troposphere: Application to ozone production efficiency, J. Geophys. Res., 116, D12306, doi:10.1029/2010JD015056, 2011.

Crounse, J. D., McKinney, K. A., Kwan, A. J., and Wennberg, P. O.: Measurement of gas-phase hydroperoxides by chemical ionization mass spectrometry, Anal. Chem., 78, 6726-6732, 202006.

Crounse, J. D., DeCarlo, P. F., Blake, D. R., Emmons, L. K., Campos, T. L., Apel, E. C., Clarke, A. D., Weinheimer, A. J., McCabe, D. C., Yokelson, R. J., Jimenez, J. L., and Wennberg, P. O.: Biomass burning and urban air pollution over the Central Mexican Plateau, Atmos. Chem. Phys., 9, 4929-4944, doi:10.5194/acp-9-4929-2009, 2009.

Dufour, G., Eremenko, M., Griesfeller, A., Barret, B., LeFlochmoën, E., Clerbaux, C., Hadji-Lazaro, J., Coheur, P.-F., and Hurtmans, D.: Validation of three different scientific ozone products retrieved from IASI spectra using ozonesondes, Atmos. Meas. Tech. Discuss., 4, 5425-5479, doi:10.5194/amtd-4-54252011, 2011.

Emmons, L. K., Hauglustaine, D. A., Müller, J.-F., Carroll, M. A., Brasseur, G. P., Brunner, D., Stahelin, J., Thouret, V., and Marenco, A.: Data composites of airborne observations of tropospheric ozone and its precursors, J. Geophys. Res., 105, 2049720538, 2000.

Emmons, L. K., Walters, S., Hess, P. G., Lamarque, J.-F., Pfister, G. G., Fillmore, D., Granier, C., Guenther, A., Kinnison, D., Laepple, T., Orlando, J., Tie, X., Tyndall, G., Wiedinmyer, C., Baughcum, S. L., and Kloster, S.: Description and evaluation of the Model for Ozone and Related chemical Tracers, version 4 (MOZART-4), Geosci. Model Dev., 3, 43-67, doi:10.5194/gmd3-43-2010, 2010a.

Emmons, L. K., Apel, E. C., Lamarque, J.-F., Hess, P. G., Avery, M., Blake, D., Brune, W., Campos, T., Crawford, J., DeCarlo, P. F., Hall, S., Heikes, B., Holloway, J., Jimenez, J. L., Knapp, D. J., Kok, G., Mena-Carrasco, M., Olson, J., O’Sullivan, D., Sachse, G., Walega, J., Weibring, P., Weinheimer, A., and Wiedinmyer, C.: Impact of Mexico City emissions on regional air quality from MOZART-4 simulations, Atmos. Chem. Phys., 10, 6195-6212, doi:10.5194/acp-10-6195-2010, 2010b.

Fisher, H., Wienhold, F. G., Hoor, P., Bujok, O., Schiller, C., Siegmund, P., Ambaum, M., Scheeren, H. A., and Lelieveld, J.: 
Tracer correlations in the northern high latitude lowermost stratosphere: Influence of cross-tropopause mass exchange, Geophys. Res. Lett., 27, 97-100, 2000.

Fisher, J. A., Jacob, D. J., Purdy, M. T., Kopacz, M., Le Sager, P., Carouge, C., Holmes, C. D., Yantosca, R. M., Batchelor, R. L., Strong, K., Diskin, G. S., Fuelberg, H. E., Holloway, J. S., Hyer, E. J., McMillan, W. W., Warner, J., Streets, D. G., Zhang, Q., Wang, Y., and Wu, S.: Source attribution and interannual variability of Arctic pollution in spring constrained by aircraft (ARCTAS, ARCPAC) and satellite (AIRS) observations of carbon monoxide, Atmos. Chem. Phys., 10, 977-996, doi:10.5194/acp-10-977-2010, 2010.

Generoso, S., Bey, I., Attie, J.-L., and Breon, F.-M.: A satelliteand model-based assessment of the 2003 Russian forest ?res: impact on the Arctic region, J. Geophys. Res., 112, D15302, doi:10.1029/2006JD008344, 2007.

Hannigan, J. W., Coffey, M. T., and Goldman, A.: Semiautonomous FTS Observation System for Remote Sensing of Stratospheric and Tropospheric Gases, J. Atmos. Oceanic Technol., 26, 18141828, doi:10.1175/2009JTECHA1230.1, 2008.

Hudman, R. C., Jacob, D. J., Cooper, O. R., Evans, M. J., Heald, C. L., Park, R. J., Fehsenfeld, F., Flocke, F., Holloway, J., Hubler, G., Kita, K., Koike, M., Kondo, Y., Neuman, A., Nowak, J., Oltmans, S., Parrish, D., Roberts, J. M., and Ryerson, T.: Ozone production in transpacific Asian pollution plumes and implications for ozone air quality in California, J. Geophys. Res., 109, D23S10, doi:10.1029/2004JD004974, 2004.

Hudman, R. C., Jacob, D. J., Turquety, S., Leibensperger, E. M., Murray, L. T., Wu, S., Gilliland, A. B., Avery, M., Bertram, T. H., and Brune, W.: Surface and lightning sources of nitrogen oxides over the United States: Magnitudes, chemical evolution, and outflow, J. Geophys. Res.-Atmos, 112, D12S05, doi:10.1029/2006JD007912, 2007.

Huey, L. G., Tanner, D. J., Slusher, D. L., Dibb, J. E., Arimoto, R., Chen, G., Davis, D., Buhr, M. P., Nowak, J. B., Mauldin III, R. L., Eisele, F. L., and Kosciuch, E.: CIMS measurements of $\mathrm{HNO}_{3}$ and $\mathrm{SO}_{2}$ at the South Pole during ISCAT 2000, Atmos. Environ., 5411-5421, doi:10.1016/j.atmosenv.2004.04.037, 2004.

Hurtmans, D., Coheur, P.-F., Wespes, C., Clarisse, L., Scharf, O., Clerbaux, C., Hadji-Lazaro, J. George, M., and Turquety, S.: FORLI radiative transfer and retrieval code for IASI, Journal of Quantitative Spectroscopy and Radiative Transfer, submitted, 2011.

Irie, H., Sugita, T., Nakajima, H., Yokota, T., Oelhaf, H., Wetzel, G., Toon, G. C., Sen, B., Santee, M. L., Terao, Y., Saitoh, N., Ejiri, M. K., Tanaka, T., Kondo, Y., Kanzawa, H., Kobayashi, H., and Sasano, Y.: Validation of stratospheric nitric acid profiles observed by Improved Limb Atmospheric Spectrometer (ILASII), J. Geophys. Res., 111, D11S03, doi:10.1029/2005JD006115, 2006.

Jacob, D. J., Crawford, J. H., Maring, H., Clarke, A. D., Dibb, J. E., Emmons, L. K., Ferrare, R. A., Hostetler, C. A., Russell, P. B., Singh, H. B., Thompson, A. M., Shaw, G. E., McCauley, E., Pederson, J. R., and Fisher, J. A.: The Arctic Research of the Composition of the Troposphere from Aircraft and Satellites (ARCTAS) mission: design, execution, and first results, Atmos. Chem. Phys., 10, 5191-5212, doi:10.5194/acp-10-5191-2010, 2010.

Kinnison, D., Brasseur, G. P., Walters, S., Garcia, R. R., Marsh, D.
R., Sassi, F., Harvey, V. L., Randall, C. E., Emmons, L., Lamarque, J. F., Hess, P., Orlando, J. J., Tie, X.X., Randel, W., Pan, L.L., Gettelman, A., Granier, C., Diehl, T., Niemeier, U., and Simmons, A. J.: Sensitivity of chemical tracers to meteorological parameters in the MOZART-3 chemical transport model, J. Geophys. Res., 112, D20302, doi:10.1029/2006JD007879, 2007.

Kleinman, L. I., Daum, P. H., Lee, Y.-N., Nunnermacker, L. J., and Springston, S. R.: Ozone production efficiency in an urban area, J. Geophys. Res., 107, 4733, doi:10.1029/2002JD002529, 2002.

Klonecki, A., Hess, P., Emmons, L., Smith, L., Orlando, J., and Blake, D.: Seasonal changes in the transport of pollutants into the Arctic troposphere-model study, J. Geophys. Res., 108, 8367, doi:10.1029/2002JD002199, 2003.

Kurylo, M. J.: Network for the detection of stratospheric change (NDSC), Proc. Soc. Photo-Opt.Instrum.Eng.,1491,168$174,1991$.

Kurylo, M. J. and Zander, R.: The NDSC - its status after 10 years of operation. Proceedings of the XIX quadrennial ozone symposium, Hokkaido University Sapporo, Japan, 167-168, 2000.

Lamarque, J.-F., Hess, P., Emmons, L., Buja, L., Washington, W., and Granier, C.: Tropospheric ozone evolution between 1890 and 1990, J. Geophys. Res., 110, D08304, doi:10.1029/2004JD005537, 2005.

Lamarque, J.-F., Bond, T. C., Eyring, V., Granier, C., Heil, A., Klimont, Z., Lee, D., Liousse, C., Mieville, A., Owen, B., Schultz, M. G., Shindell, D., Smith, S. J., Stehfest, E., Van Aardenne, J., Cooper, O. R., Kainuma, M., Mahowald, N., McConnell, J. R., Naik, V., Riahi, K., and van Vuuren, D. P.: Historical (1850-2000) gridded anthropogenic and biomass burning emissions of reactive gases and aerosols: methodology and application, Atmos. Chem. Phys., 10, 7017-7039, doi:10.5194/acp10-7017-2010, 2010.

Leung, F.-Y., Logan, J. A., Park, R., Hyer, E., Kasischke, E., Streets, D. and Yurganov, L.: Impacts of enhanced biomass burning in the boreal forests in 1998 on tropospheric chemistry and the sensitivity of model results to the injection height of emissions, J. Geophys. Res., 112, D10313, doi:doi:10.1029/2006JD007281, 2007.

Liang, Q., Jaegle, L., Jaffe, D. A., Weiss-Penzias, P., Heckman, A., and Snow, J. A.: Long-range transport of Asian pollution to the northeast Pacific: Seasonal variations and transport pathways of carbon monoxide, J. Geophys. Res., 109, D23S07, doi:10.1029/2003JD004402, 2004.

Liang, Q., Douglass, A. R., Duncan, B. N., Stolarski, R. S., and Witte, J. C.: The governing processes and timescales of stratosphere-to-troposphere transport and its contribution to ozone in the Arctic troposphere, Atmos. Chem. Phys., 9, 30113025, doi:10.5194/acp-9-3011-2009, 2009.

Lindenmaier, R., Batchelor, R. L., Strong, K., Fast, H., Goutail, F., Kolonjari, F., McElroy, C. T., Mittermeier, R. L., and Walker, K. A.: An evaluation of infrared microwindows for ozone retrievals using the Eureka Bruker 125HR Fourier transform spectrometer, J. Quant. Spectrosc. Ra., 111, 569-585, 2010.

Liu, H., Jacob, D. J., Bey, I., Yantosca, R. M., Duncan, B. N., and Sachse, G. W.: Transport pathways for Asian pollution out?ow over the Paci?c: Interannual and seasonal variations, J. Geophys. Res., 108, 8786, doi:10.1029/2002JD003102, 2003.

McPeters, R. D., Labow, G. J., and Logan, J. A.: Ozone climatological profiles for satellite retrieval algorithms, J. Geophys. Res.-Atmos., 112, D05308, doi:10.1029/2005JD006823, 2007. 
Miyazaki, Y., Kondo, Y., Koike, M., Fuelberg, H. E., Kiley, C. M., Kita, K., Takegawa, N., Sachse, G. W., Flocke, F., Weinheimer, A. J., Singh, H. B., Eisele, F. L., Zondlo, M., Talbot, R. W., Sandholm, S. T., Avery, M. A., and Blake, D. R.: Synoptic-scale transport of reactive nitrogen over the western Pacific in spring, J. Geophys. Res., 108, 8788, doi:10.1029/2002JD003248, 2003.

Murphy, D. M., Fahey, D. W., Proffitt, M. H., Liu, S. C., Chan, K. R., Eubank, C. S., Kawa, S. R., and Kelly, K. K.: Reactive nitrogen and its correlation with ozone in the lower stratosphere and upper troposphere, J. Geophys. Res., 98, 8751-8773, 1993.

Neuman, J. A., Gao, R. S., Fahey, D. W., Holecek, J. C., Ridley, B. A., Walega, J. G., Grahek, F. E., Richard, E. C., McElroy, C. T., Thompson, T. L., Elkins, J. W., Moore, F. L., and Ray, E. A.: In situ measurements of $\mathrm{HNO}_{3}, \mathrm{NO}_{\mathrm{y}}, \mathrm{NO}$, and $\mathrm{O}_{3}$ in the lower stratosphere and upper troposphere, Atmos. Environ., 35, 5789-5797, 2001.

Neuman, J. A., Parrish, D. D., Trainer, M., Ryerson, T. B., Holloway, J. S., Nowak, J. B., Swanson, A., Flocke, F., Roberts, J. M., Brown, S. S., Stark, H., Sommariva, R., Stohl, A., Peltier, R., Weber, R., Wollny, A. G., Sueper, D. T., Hubler, G., and Fehsenfeld, F. C.: Reactive nitrogen transport and photochemistry in urban plumes over the North Atlantic Ocean, J. Geophys. Res., 111, D23S54, doi:10.1029/2005JD007010, 2006.

Pfister, G. G., Emmons, L. K., Hess, P. G., Honrath, R., Lamarque, J.-F., Val Martin, M., Owen, R. C., Avery, M. A., Browell, E. V., Holloway, J. S., Nedelec, P., Purvis, R., Ryerson, T. B., Sachse, G. W., and Schlager, H.: Ozone production from the 2004 North American boreal fires, J. Geophys. Res., 111, D24S07, doi:10.1029/2006JD007695, 2006.

Pfister, G. G., Emmons, L. K., Hess, P. G., Lamarque, J.-F., Thompson, A. M., and Yorks, J. E.: Analysis of the summer 2004 ozone budget over the United States using Intercontinental Transport Experiment Ozonesonde Network Study (IONS) observations and Model of Ozone and Related Tracers (MOZART-4) simulations, J. Geophys. Res., 113, D23306, doi:10.1029/2008JD010190, 2008.

Pommier, M., Law, K. S., Clerbaux, C., Turquety, S., Hurtmans, D., Hadji-Lazaro, J., Coheur, P.-F., Schlager, H., Ancellet, G., Paris, J.-D., Nédélec, P., Diskin, G. S., Podolske, J. R., Holloway, J. S., and Bernath, P.: IASI carbon monoxide validation over the Arctic during POLARCAT spring and summer campaigns, Atmos. Chem. Phys., 10, 10655-10678, doi:10.5194/acp-1010655-2010, 2010.

Popp, P. J., Marcy, T. P., Gao, R. S., Watts, L. A., Fahey, D. W., Richard, E. C., Oltmans, S. J., Santee, M. L., Livesey, N. J., Froidevaux, L., Sen, B., Toon, G. C., Walker, K. A., Boone, C. D., and Bernath, P. F.: Stratospheric correlation between nitric acid and ozone, J. Geophys. Res., 114, D03305, doi:10.1029/2008JD010875, 2009.

Preston, C. M. and Schmidt, M. W. I.: Black (pyrogenic) carbon: a synthesis of current knowledge and uncertainties with special consideration of boreal regions, Biogeosciences, 3, 397-420, doi:10.5194/bg-3-397-2006, 2006.

Price, H. U., Jaffe, D. A., Cooper, O. R., and Doskey, P. V.: Photochemistry, ozone production, and dilution during long-range transport episodes from Eurasia to the northwest United States, J. Geophys. Res., 109, D23S13, doi:10.1029/2003JD004400, 2004.

Querol, X., Pey, J., Minguillón, M. C., Pérez, N., Alastuey, A.,
Viana, M., Moreno, T., Bernabé, R. M., Blanco, S., Cárdenas, B., Vega, E., Sosa, G., Escalona, S., Ruiz, H., and Artíñano, B.: PM speciation and sources in Mexico during the MILAGRO-2006 Campaign, Atmos. Chem. Phys., 8, 111-128, doi:10.5194/acp8-111-2008, 2008.

Ramaswamy, V., Boucher, O., Haigh, J., Hauglustaine, D., Haywood, J., Myhre, G., Nakajima, T., Shi, G. Y., and Solomon, S.: Radiative forcing of climate change, in Climate Change 2001: The Scientific Basis, edited by: Houghton, J. T., Ding, Y., Griggs, D. J., Noguer, M., van der Linden, P. J., Dai, X., Maskell, K., and Johnson, C. A., 349-416, Cambridge Univ. Press, New York, 2001.

Rastigejev, Y., Park, R., Brenner, M. P., and Jacob, D. J.: Resolving intercontinental pollution plumes in global models of atmospheric transport, J. Geophys. Res., 115, D02302, doi:10.1029/2009JD012568, 2009.

Ridley, B. A., Walega, J. G. Dye, J. E., and Grahek, F. E.: Distributions of $\mathrm{NO}, \mathrm{NO}_{\mathrm{x}}, \mathrm{NO}_{\mathrm{y}}$, and $\mathrm{O}_{3}$ to $12 \mathrm{~km}$ altitude during the summer monsoon season over New Mexico, J. Geophys. Res., 99, 25519-25534, 1994.

Richter, A., Burrows, J. P., Nuß, H., Granier, C., and Niemeier, U.: Increase in tropospheric nitrogen dioxide over China observed from space, Nature, 437, 129-132, doi:10.1038/nature04092, 2005.

Rodgers, C. D.: Inverse methods for atmospheric sounding: theory and practice, Ser. Atmos. Ocean. Planet. Phys. 2, World Sci., Hackensack, NJ, 2000.

Scannell, C., Hurtmans, D., Boynard, A., Hadji-Lazaro, J., George, M., Delcloo, A., Tuinder, O., Coheur, P.-F., and Clerbaux, C.: A review of the ozone hole from 2008 to 2010 as observed by IASI, Atmos. Meas. Tech. Discuss., 4, 4717-4752, doi:10.5194/amtd4-4717-2011, 2011.

Schneider J., Arnold, F., Curtius, J., Sierau, B., Fischer, H., Hoor, P., Wienhold, F. G., Parchatka, U., Zhang, Y. C., Schlager, H., Ziereis, H., Feigl, Ch., Lelieveld, J., Scheeren, H. A., and Bujok, O.: The temporal evolution of the ratio $\mathrm{HNO}_{3} / \mathrm{NO}_{\mathrm{y}}$ in the Arctic lower stratosphere from January to March 1997, Geophys. Res. Lett, 26, 1125-1128, 1999.

Shindell, D. T., Chin, M., Dentener, F., Doherty, R. M., Faluvegi, G., Fiore, A. M., Hess, P., Koch, D. M., MacKenzie, I. A., Sanderson, M. G., Schultz, M. G., Schulz, M., Stevenson, D. S., Teich, H., Textor, C., Wild, O., Bergmann, D. J., Bey, I., Bian, H., Cuvelier, C., Duncan, B. N., Folberth, G., Horowitz, L. W., Jonson, J., Kaminski, J. W., Marmer, E., Park, R., Pringle, K. J., Schroeder, S., Szopa, S., Takemura, T., Zeng, G., Keating, T. J., and Zuber, A.: A multi-model assessment of pollution transport to the Arctic, Atmos. Chem. Phys., 8, 5353-5372, doi:10.5194/acp-8-5353-2008, 2008.

Shon, Z.-H., Madronich, S., Song, S.-K., Flocke, F. M., Knapp, D. J., Anderson, R. S., Shetter, R. E., Cantrell, C. A., Hall, S. R., and Tie, X.: Characteristics of the $\mathrm{NO}-\mathrm{NO}_{2}-\mathrm{O}_{3}$ system in different chemical regimes during the MIRAGE-Mex field campaign, Atmos. Chem. Phys., 8, 7153-7164, doi:10.5194/acp-8-7153-2008, 2008.

Singh, H.B., Hertlth, D., Kolyer, R., Salas, L., Bradshaw, J. D., Sandholm, S. T., Davis, D. D., Crawford, J.,Kondo, Y., Koike, M., Talbot, R., Gregory, G. L., Sachse, G. W.,Browell, E., Blake, D. R., Rowland, F. S., Newell, R.,Merrill, J., Heikes, B., Liu, S.C., Crutzen, P. J., and Kanakidou, M.: Reactive nitrogen and 
ozone over the western Pacific: Distribution, partitioning, and sources, J. Geophys. Res., 101, 1793-1808, 1996.

Stohl, A.: Characteristics of atmospheric transport into the Arctic troposphere, J. Geophys. Res., 111, D11306, doi:10.1029/2005JD006888, 2006.

Stohl, A., Berg, T., Burkhart, J. F., Fjæraa, A. M., Forster, C., Herber, A., Hov, Ø., Lunder, C., McMillan, W. W., Oltmans, S., Shiobara, M., Simpson, D., Solberg, S., Stebel, K., Ström, J., Tørseth, K., Treffeisen, R., Virkkunen, K., and Yttri, K. E.: Arctic smoke - record high air pollution levels in the European Arctic due to agricultural fires in Eastern Europe in spring 2006, Atmos. Chem. Phys., 7, 511-534, doi:10.5194/acp-7-511-2007, 2007.

Talbot, R. W., Dibb, J. E., Lefer, B. L., Scheuer, E. M., Bradshaw, J. D., Sandholm, S. T., Smyth, S., Blake, D. R., Blake, N. J., Sachse, G. W., Collins, J. E., and Gregory, G. L.: Large-scale distributions of tropospheric nitric, formic, and acetic acids over the western Pacific basin during wintertime, Geophys. Res. Lett, 102, 28303-28313, 1997.

Tilmes, S., Emmons, L. K., Law, K. S., Ancellet, G., Schlager, H., Paris, J.-D., Fuelberg, H. E., Streets, D. G., Wiedinmyer, C., Diskin, G. S., Kondo, Y., Holloway, J., Schwarz, J. P., Spackman, J. R., Campos, T., Nédélec, P., and Panchenko, M. V.: Source contributions to Northern Hemisphere CO and black carbon during spring and summer 2008 from POLARCAT and START08/preHIPPO observations and MOZART-4, Atmos. Chem. Phys. Discuss., 11, 5935-5983, doi:10.5194/acpd-115935-2011, 2011.

Trainer, M., Parrish, D.D., Buhr, M.P., Norton, R. B., Fehsenfeld, F. C., Anlauf, K. G., Bottenheim, J. W., Tang, Y. Z., Wiebe, H. A., Roberts, J. M., Tanner, R. L., Newman, L., Bowersox, V. C., Meagher, J. F., Olszyna, K. J., Rodgers, M. O., Wang, T., Berresheim, H., Demerjian, K. L., and Roychowdhury, U. K.: Correlation of ozone with $\mathrm{NO}_{\mathrm{y}}$ in photochemically aged air, J. Geophys. Res., 98, 2917-2925, 1993.

Turquety, S., Logan, J. A., Jacob, D. J., Hudman, R. C., Leung, F. Y., Heald, C. L., Yantosca, R. M., Wu, S., Emmons, L. K., Edwards, D. P., and Sachse, G.W.: Inventory of boreal fire emissions for North America in 2004: the importance of peat burning and pyro-convective injection, J. Geophys. Res. 112, D12S03, doi:10.1029/2006JD007281, 2007.

Turquety, S., Hurtmans, D., Hadji-Lazaro, J., Coheur, P.-F., Clerbaux, C., Josset, D., and Tsamalis, C.: Tracking the emission and transport of pollution from wildfires using the IASI CO retrievals: analysis of the summer 2007 Greek fires, Atmos. Chem. Phys., 9, 4897-4913, doi:10.5194/acp-9-4897-2009, 2009.

Vigouroux, C., De Mazière, M., Errera, Q., Chabrillat, S., Mahieu, E., Duchatelet, P., Wood, S., Smale, D., Mikuteit, S., Blumenstock, T., Hase, F., and Jones, N.: Comparisons between groundbased FTIR and MIPAS $\mathrm{N}_{2} \mathrm{O}$ and $\mathrm{HNO}_{3}$ profiles before and after assimilation in BASCOE, Atmos. Chem. Phys., 7, 377-396, doi:10.5194/acp-7-377-2007, 2007.
Warneke, C., Bahreini, R., Brioude, J., Brock, C. A., de Gouw, J. A., Fahey, D. W., Froyd, K. D., Holloway, J. S., Middlebrook, A., Miller, L., Montzka, S., Murphy, D. M., Peischl, J., Ryerson, T. B., Schwarz, J. P., Spackman, J. R., and Veres, P.: Biomass burning in Siberia and Kazakhstan as the main source for Arctic Haze over the Alaskan Arctic in April 2008, Geophys. Res. Lett., 36, L02813, doi:10.1029/2008GL036194, 2009.

Weinheimer, A. J., Walega, J. G., Ridley, B. A., Gary, B. L., Blake, D. R., Blake, N. J., Rowland, F. S., Sachse, G. W., Anderson, B. E., and Collins, J. E.: Meridional distributions of $\mathrm{NO}_{\mathrm{x}}, \mathrm{NO}_{\mathrm{y}}$, and other species in the lower stratosphere and upper troposphere during AASE II, Geophys. Res. Lett., 21, 2583-2586, 1994.

Wespes, C., Hurtmans, D., Clerbaux, C., Santee, M. L., Martin, R. V., and Coheur, P. F.: Global distributions of nitric acid from IASI/MetOP measurements, Atmos. Chem. Phys., 9, 7949-7962, doi:10.5194/acp-9-7949-2009, 2009.

Wiedinmyer, C., Quayle, B., Geron, C., Belote, A., McKenzie, D., Zhang, X., O'Neill, S., and Wynne, K.: Estimating emissions from fires in North America for air quality modeling, Atmos. Environ., 40, 3419-3432, 2006.

Wiedinmyer, C., Akagi, S. K., Yokelson, R. J., Emmons, L. K., AlSaadi, J. A., Orlando, J. J., and Soja, A. J.: The Fire INventory from NCAR (FINN): a high resolution global model to estimate the emissions from open burning, Geosci. Model Dev., 4, 625641, doi:10.5194/gmd-4-625-2011, 2011.

Yienger, J. and Levy, H.: Empirical model of global soil biogenic $\mathrm{NO}_{\mathrm{x}}$ emissions, J. Geophys. Res., 100, 11447-11464, 1995.

Zellweger, C., Forrer, J., Hofer, P., Nyeki, S., Schwarzenbach, B., Weingartner, E., Ammann, M., and Baltensperger, U.: Partitioning of reactive nitrogen $\left(\mathrm{NO}_{\mathrm{y}}\right)$ and dependence on meteorological conditions in the lower free troposphere, Atmos. Chem. Phys., 3, 779-796, doi:10.5194/acp-3-779-2003, 2003.

Zhang, L., Jacob, D. J., Boersma, K. F., Jaffe, D. A., Olson, J. R., Bowman, K. W., Worden, J. R., Thompson, A. M., Avery, M. A., Cohen, R. C., Dibb, J. E., Flock, F. M., Fuelberg, H. E., Huey, L. G., McMillan, W. W., Singh, H. B., and Weinheimer, A. J.: Transpacific transport of ozone pollution and the effect of recent Asian emission increases on air quality in North America: an integrated analysis using satellite, aircraft, ozonesonde, and surface observations, Atmos. Chem. Phys., 8, 6117-6136, doi:10.5194/acp-8-6117-2008, 2008.

Zhang, Q., Streets, D. G., Carmichael, G. R., He, K. B., Huo, H., Kannari, A., Klimont, Z., Park, I. S., Reddy, S., Fu, J. S., Chen, D., Duan, L., Lei, Y., Wang, L. T., and Yao, Z. L.: Asian emissions in 2006 for the NASA INTEX-B mission, Atmos. Chem. Phys., 9, 5131-5153, doi:10.5194/acp-9-5131-2009, 2009. 